Article

\title{
Geoenvironmental Implications and Biocenosis of Freshwater Lakes in the Arid Zone of East Kazakhstan
}

\author{
Talant N. Samarkhanov ${ }^{1}$, Anar B. Myrzagaliyeva ${ }^{2, *}$, Jiri Chlachula ${ }^{3,4, *}$, Ludmila B. Kushnikova ${ }^{5}$, \\ Jolanta Czerniawska ${ }^{6}$ and Sayan B. Nigmetzhanov ${ }^{5}$
}

Citation: Samarkhanov, T.N.; Myrzagaliyeva, A.B.; Chlachula, J.; Kushnikova, L.B.; Czerniawska, J.; Nigmetzhanov, S.B.

Geoenvironmental Implications and Biocenosis of Freshwater Lakes in the Arid Zone of East Kazakhstan. Sustainability 2021, 13, 5756. https://doi.org/10.3390/su13105756

Academic Editors:

Konstantinos Stefanidis and Elias Dimitriou

Received: 23 January 2021

Accepted: 20 April 2021

Published: 20 May 2021

Publisher's Note: MDPI stays neutral with regard to jurisdictional claims in published maps and institutional affiliations.

Copyright: (c) 2021 by the authors. Licensee MDPI, Basel, Switzerland. This article is an open access article distributed under the terms and conditions of the Creative Commons Attribution (CC BY) license (https:/ / creativecommons.org/licenses/by/ $4.0 /)$.
1 Department of Physical and Economic Geography, Faculty of Natural Sciences, L.N. Gumilyov Eurasian National University, Nur-Sultan 010010, Kazakhstan; talant.68@mail.ru

2 Higher School of Natural Sciences, Astana International University, Nur-Sultan 010000, Kazakhstan

3 Environmental Research Centre, Nerudova 2181, 68603 Stare Mesto, Czech Republic

4 Department of Geomorphology, Institute of Geoecology and Geoinformation, A. Mickiewicz University, 61-680 Poznań, Poland

5 Altai Branch of LLP «Fisheries Research and Production Center», Ust-Kamenogorsk 070004, Kazakhstan; lbk249157@mail.ru (L.B.K.); sayan_95.kz@bk.ru (S.B.N.)

6 Anthropocene Research Unit, Institute of Geoecology and Geoinformation, Adam Mickiewicz University, 61-680 Poznań, Poland; jolczer@amu.edu.pl

* Correspondence: an.myrzagaliyeva@gmail.com (A.B.M.); Altay@seznam.cz (J.C.)

\begin{abstract}
Steppe and semi-desert lakes of Central Asia represent unique and still poorly known aquatic ecosystems. The paper provides summaries of multi-proxy environmental and biological investigations of the previously unexplored ground of Sibe lakes in the naturally pristine zone of East Kazakhstan, and of their contributions to people. Data on the taxonomic composition of zooplankton and zoobenthos of these freshwater lacustrine basins are presented in terms of the species' frequency of occurrence; the abundance of the aquatic biomass and the analyzed water geochemical variables insofar as they are dependent and correlative. The qualitative and quantitative records display variability in the biocenosis diversity due to the lakes' geochemistry and hydrology differencessome lakes being oligotrophic and others being moderately trophic. In the latter case, the lakes characterized by an increased macrozoobenthos biomass are favourable for local ichthyofauna. Saprobiological analysis reveals the predominance of $\beta$-saprobic species in the zooplankton composition pointing to slight or moderate pollution of surface waters due to natural biotic substances. This observation is in agreement with differences in the water quality of solitary lakes. The uneven distributions of benthic invertebrates (in terms of taxonomy and species populations) in the water bodies suggest specific hydro-ecological conditions that predetermine the structure of the lakes' biocenosis. The littoral part of the lakes is characterized by the highest abundance of zooplankton and benthic fauna. The Sibe lakes are an example of an autonomous functioning of the lacustrine basins in the upland arid steppe zone, which is characterized by pronounced climate "continentality" and a high level of the sub-aquatic flora and fauna endemism. The present results are relevant to the understanding of the ecosystems' dynamics and the modern anthropogenic impacts upon the pristine parkland-steppe landscapes of Central Asia, with implications for regional nature protection and sustainable eco-recreation.
\end{abstract}

Keywords: East Kazakhstan; lakes; hydrogeology; aquatic ecosystems; macrozoobenthos; sustainable water management; environmental conservation 


\section{Introduction}

Lakes play important roles in regional hydrology, environmental dynamics and aquatic biota diversity [1-3]. Lacustrine and riverine systems are relevant indications of regional environmental stability and ecological sanity with zooplankton and phytoplankton as the main indicators [4-7]. Lakes also significantly enhance the attractiveness and scenic beauty of the landscape, and expand the potential of free-time activities. About $85-90 \%$ of the long-term and $90-95 \%$ of the short-term recreation facilities worldwide are positioned on banks of water bodies exposed to climate change and anthropogenic use [8,9]. In Kazakhstan, investigations of the lake basins were regularly carried out until the 1980s. The more recent studies [10-17] have focused mostly on the largest water bodies, such as the Ile-Balkhash, the lakes of the Aral-Syrdarya basin or the Shushinsko-Borovoye lakes. Research on the country's freshwater and saline lacustrine basins largely focused on the phytoplankton biomass and taxonomic variations, and the spatial distribution in terms of estimating the long-term changes in water quality [18-27] and the site-specific hydraulic water conditions with implications to agriculture, sustainable economic/public use, recreation and the aquatic biodiversity conservation [28,29].

The arid-zone freshwater lakes of Kazakhstan inspire a major interest with respect to their isolated locations amid the northern rocky massifs and in the foothills of the main mountain chain forming the eastern limits of the country. Most of the lakes are hydrologically closed, i.e., without external inlets and drainages, and thus susceptible to groundwater fluctuations and precipitation variations, affecting the hosted aquatic and littoral terrestrial biota. Because of the determinant geographic and geoenvironmental contexts, some lacustrine basins show pronounced endemism of living organisms, including persistence of relict (pre-Quaternary) taxon, indicating a long-term hydrological stability and/or single species adaptability to local natural settings. Study of the lakes' ecosystems and their dynamics is of utmost relevance for a better comprehension of biocenosis functioning, and species interactions, and their conservation. At the same time, preservation of natural balance of the lakes systems has a direct bearing for sustainable public use as naturally filtered drinking water reservoirs, regional recreation sites, and for development of fishery economy.

Location of the lake basins directly affects the corresponding geochemical characteristics of waters passing through or enclosed within the accommodating geological bodies. Other geoenvironmental factors, such as altitude, slope steepness, solar insolation and the lithic substratum weathering rates, bedrock permeability, the annual amount of precipitation, snow-cover distribution and seasonal runoff directly influence the hydrological dynamics of the Central Asia's arid-zone basins and predispose the natural ambiences for the aquatic life development. This is partly impeded by evaporation and increased salinity in the places with the reduced rain/snowfall supplying to the regional water system. The stable, groundwater-fed lakes host most unique aquatic biotopes.

The Sibe lakes located in picturesque rolling steppes of East Kazakhstan represent one of the most appealing and biologically precious natural places of the region. Encircled by vegetation-free granitic hills, the freshwater lake system includes five lakes (Sadyrkol, Tortkara, Shalkar, Korzhynkol, Karakol) separated by parallel, S-N oriented rocky ridges rising above the surrounding landscape of the Koktau Mountains (the Kalba Range) at the Southern Altai foothills at altitude of 710-880 m (Figure 2). Until recently, the lakes have remained largely unexplored in terms of hydrology, hydrochemistry and biology. Some preliminary investigations relate to the aquatic algae taxonomy $[30,31]$ and the terrestrial flora [32]. The first general description of the lake basins from 1980s was limited to their physical and chemical characteristics [33].

With respect to the supreme natural beauty, but a relatively short distance from the regional administrative centre Ust'-Kamenogork (Oskemen), the Sibe lakes are becoming increasingly visited by tourists and holiday visitors on a regular basis. This creates an acute need for protection of the pristine lake basins' in view to their exceptional geo-setting, the unique aquatic and terrestrial biotopes, and the reservoirs' water quality. The problem of 
the lakes preservation is associated with their active use for recreational purposes, including cottage building and sportive fishing. The nearest zone along the lakeshores, as well as the close surroundings, are subjected to a rising tourism pressure and ecological threats reflected in the deteriorating water purity and a certain terrestrial biodiversity reduction in the near lakes' vicinity. The development of tourism and recreation in the region $[29,34,35]$, characterized by the broad mosaic landscape diversity [36-38], requires implementation of ecological monitoring with a water quality and biocenosis control, and study of possible changes in the structural and functional organization of aquatic ecosystems under the influence of negative environmental factors-natural/anthropogenic.

Numerous studies worldwide from various geographic and climatically specific areas show linkages of lake waters geochemistry determined by local geo-settings determined by bedrock geology, water geochemistry and hydraulic conditions, among other factors, on the aquatic biomass productivity and the composition of zooplankton [39-44], which, in turn, influence, along with precipitation regime, water quality [45]. Macrozoobenthos (the aquatic fauna at or near the bottom of a water body) [46] plays an important role in the functioning of aquatic ecosystems and ensuring the trophic relationship of species. These organisms are sensitive to changes in environmental parameters, but at the same time, may be long-term stable and sometime well adapted even to extreme environmental impacts. The existing biocenosis community in a lake body is represented by the species population quantity and diversity defined by specific microscopic life forms and other structural organic elements [47].

This study presents the results of pilot hydro-biological investigations of zooplankton and macrozoobenthos as of ecological indicators of water quality and pristine biodiversity of the Sibe lakes' complex. The main objective was to examine the working hypothesis on the influence of the locally specific abiotic conditions in the East Kazakhstan's arid steppe zone on the formation of diverse aquatic biological communities of the hydrologically isolated freshwater lake basins. Such research is novel in the broader region. Geoenvironmentally predisposed and geographically specific biocenosis variability has been documented elsewhere in the arid Central Asia, the adjacent west Mongolia and southern Siberia [48-53].The paper is aimed to contribute to a better comprehension of an independent functioning, the biotic life, the lakes' hydrology and the potential naturefriendly/sustainable exploitation of the lake systems in the dry parkland-steppes of the continental north-central Asia exposed to the progressing aridification [2,54], the associated large-scale environmental transformations and the modern anthropogenic pressure.

\section{Study Area}

\subsection{Regional Setting}

The broader study area is located close to the geographic centre of Asia delimited by the eastern flanks of the Altai-Alatau orographic system forming the natural boundary of Kazakhstan and China (Xing-Jang Province) (Figure 1). The group of Sibe lakes is found at foots of the Koktau Mountains of the Kalba Range which is an isolated orographic unit of the Kazakhstan Altai [38]. The montane relief represents a continuation of the western low-orogenic massifs on the left bank of the Irtysh. The eastern half of the Kalba Range is characterized by the E-W-oriented low-mountain topography, with the prevailing elevations 700-1300 m asl. and single peaks reaching 1400-1600 m asl. Their regional geological formations relate to the Upper Palaeozoic (Varissian) Earth crust folding succeeding the most intense Lower Palaeozoic (Caledonian) regional orographic development with granite intrusions. Extensive formations of shales, metatufs, metadrobes resulted from a low-grade regional metamorphism of fine-grained pelitic sediments. A continental planation processes following the Lower Devonian led to a complete denudation of the broader Altai area with a re-activated neotectonics during the Tertiary and early Quaternary periods, giving a rise to the present relief of East Kazakhstan [55-59]. In addition to the regional orogeny, the periodic Cainozoic glaciations, loess deposition and weathering processes modelled the present landscape relief [60-63]. 
The diversified (rainfall and snow) precipitations $(<200 \mathrm{~mm}$ in the aridest semi-deserts of the Zaisan Lake basin, and $>800 \mathrm{~mm}$ on the western slopes of the Southern Altai) in conjunction with the profiled geomorphic gradient predetermine the pronounced vegetation zonation and the regional biogeography. The principal biotopes in the adjoining midand high-elevation mountains are represented by mixed forests and the dark coniferous taiga. Arid rocky steppes, transgressing in the west into vast open grasslands, characterize the broad lowlands. The principal regional hydrological network belongs to the Irtysh River and its major tributaries (the Black Irtysh and Bukhtarma rivers) draining glacial and precipitation waters from the eastern mountain area. Perennial streams appear seasonally in the semi-deserts in the continental depressions. Lakes of diverse mineralogy (freshwater, brackish and saline) are locally found, reflecting the local micro-climate and hydro-geology conditions.

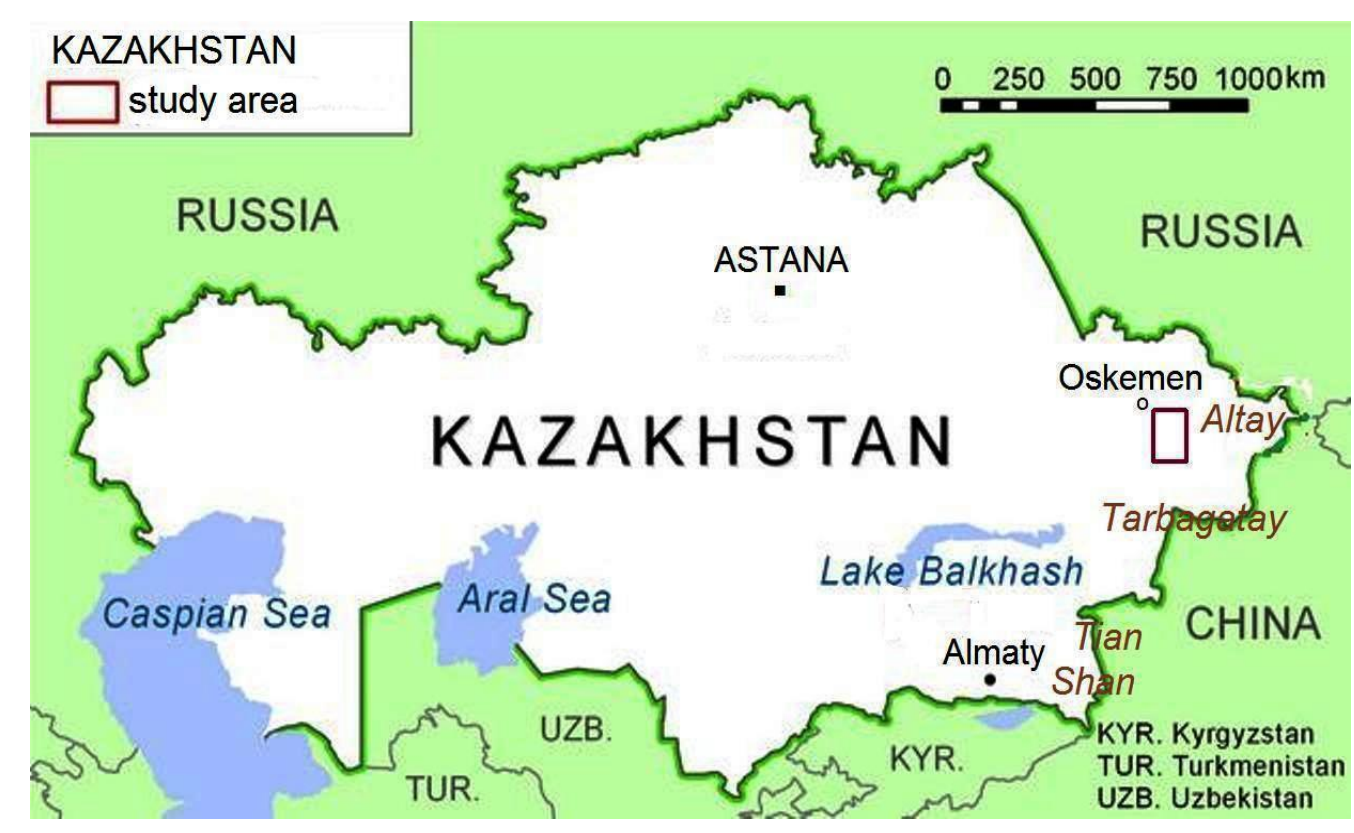

Figure 1. Geography of the study area, eastern Kazakhstan.

\subsection{Site Location}

The present topography of the Kalba Range is characterized by the flat erosional plateaus and mountain chains (900-1450 m asl. in the lakes' vicinity), separated by narrow longitudinal or transverse valleys and deep intermontane depressions [64]. The eastern mountain geographic exposures are more profiled and rocky than the western ones. The northern slopes are steep; the southern ones are gentle, gradually transgressing into the rolling-undulating plains transected by small river valleys and gullies towards the Irtysh valley broadening in the Zaisan depression. The western half of the Kalba Range (between the Bukhtarma and the Narym Rivers) is structured by low, isolated hummocky-like rocky hills adjoining the North-Central Kazakhstan Uplands.

The Kalba Mountains are built by granitic-gneissic rocks (the Del'begetey Formation) $[65,66]$. The volcanites are high acidity coarse-grain granites [67]. Erosional activity through the geological times shaped the former surface by planation into sandwich-like foliated rocky structures overlying the basal non-weathered granite masses. From the southeast, the slopes of the lakes' surrounding have oval forms (Figure 2) with just a partially developed shallow shore-zone in the southern part of the single lacustrine basins. The other sides of the lakes are bordered by steep rocky ramparts aligned from the west, north and east. 


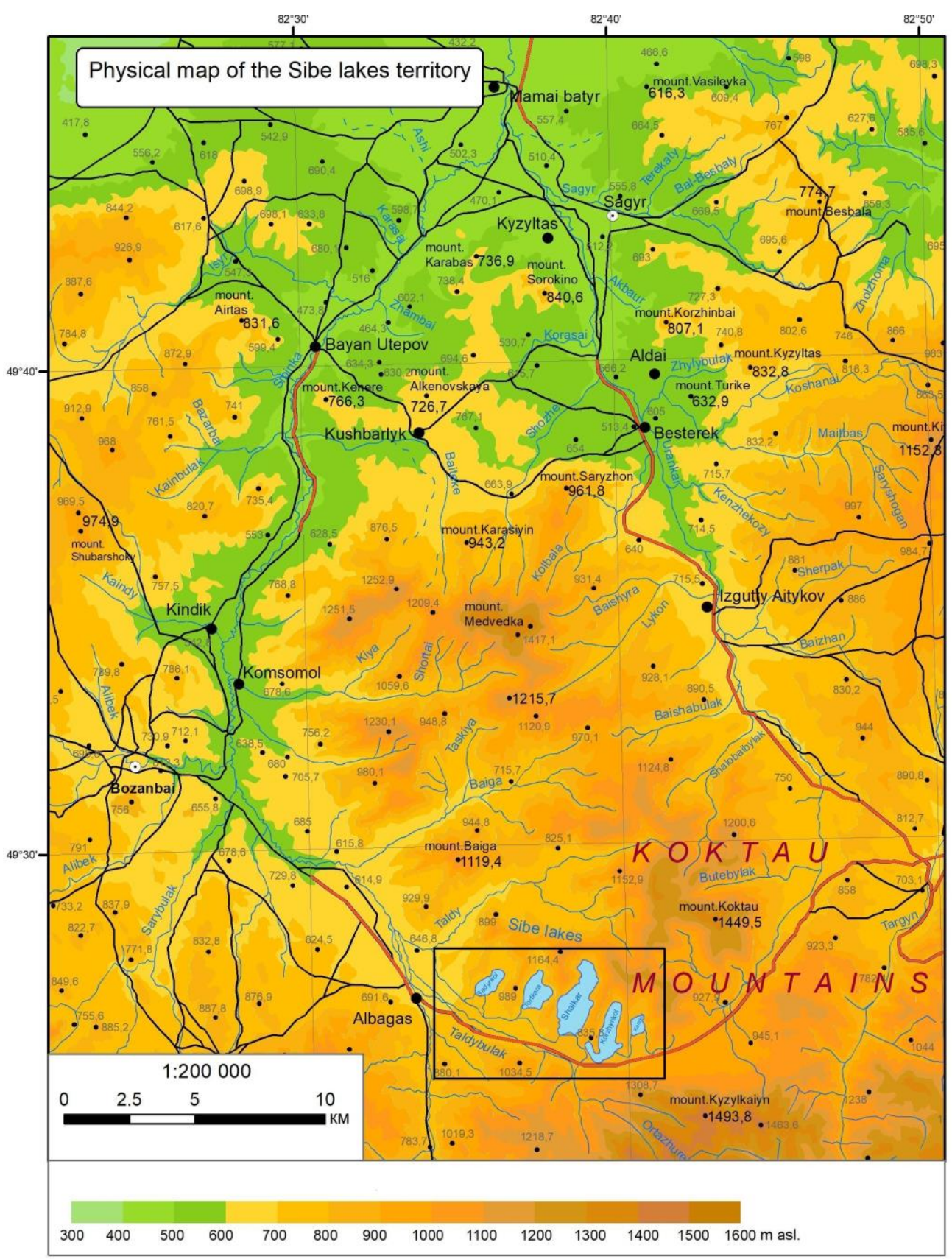

Figure 2. The regional relief map with the location of the Sibe lakes.

The climate is continental, particularly pronounced in the North-West, with warm to hot summers (average July temperature in Ust'-Kamenogorsk is $+20^{\circ} \mathrm{C}$ ) and cold winters (average January temperature $-15.4{ }^{\circ} \mathrm{C}$ ). The local climate is strongly continental and arid, with the MAAT (mean annual air temperature) $+2{ }^{\circ} \mathrm{C}$. In winter, dry south and south-western winds prevail, providing just a thin snow cover blanketing the steppes. In summer, wetter fronts from the west and NW bring most of the annual precipitations, and contributing to the late spring rainfalls, amounting $42-52 \mathrm{~mm}$ per month (May-August) [68]. The regional rain shadows from the south and the east led to the formation of semidesert/arid steppes covering most of the highland's landscape with rocky, wind-deflated and strongly weathered bedrock exposures, such as those hosting the Sibe lakes (Figure 3). The region is characterized by a high solar radiation and a low-cloudiness, corresponding to $\sim 2600$ sunshine hours per year. The topographic differences on a relatively a small area (Figure 2) contribute to the unevenness of climatic conditions with the driest in the low 
continental depressions. The rocky-steppe plateaus surrounded by the mountains are extremely cold in the wintertime with deep ground freeze and minor $(5-7 \mathrm{~cm})$ snowfall due to aridity and strong windiness contributing to the insular permafrost preservation all year-round at the $-1 \mathrm{~m}$-depth [69-72]. The xerophytic plant cover mirrors the limited water network with sparse surficial flows characterizing the broader steppe territory [73].

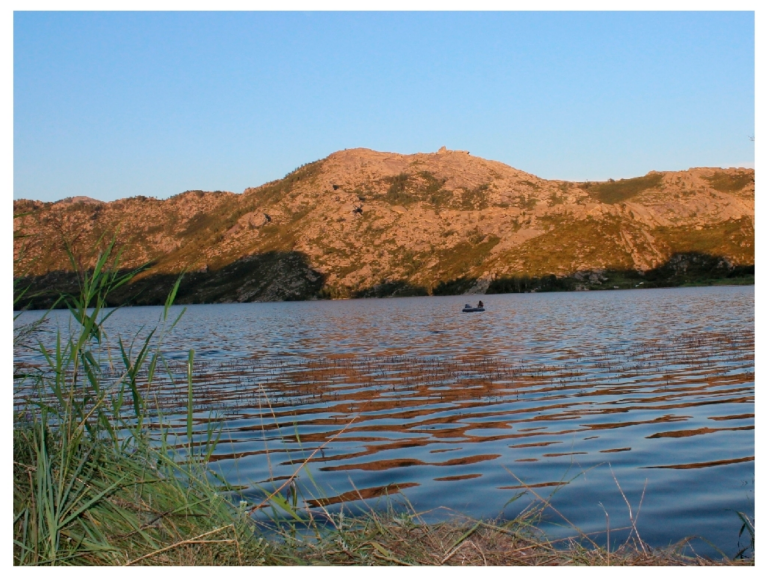

A

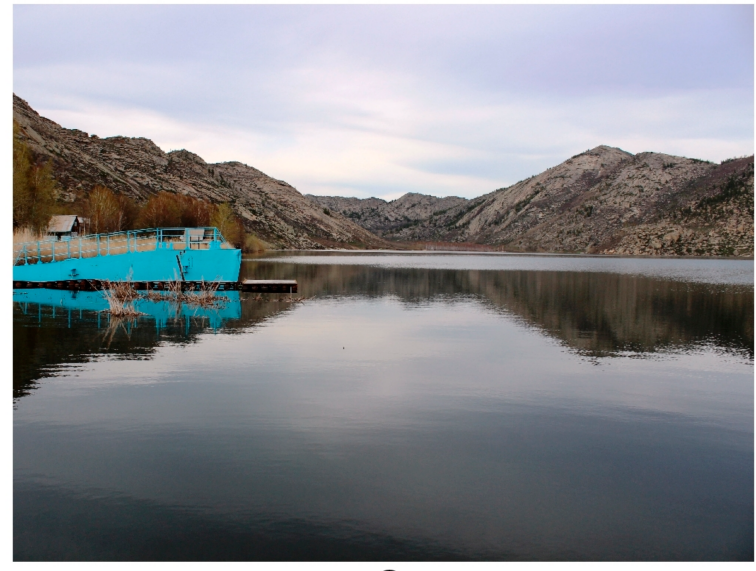

C

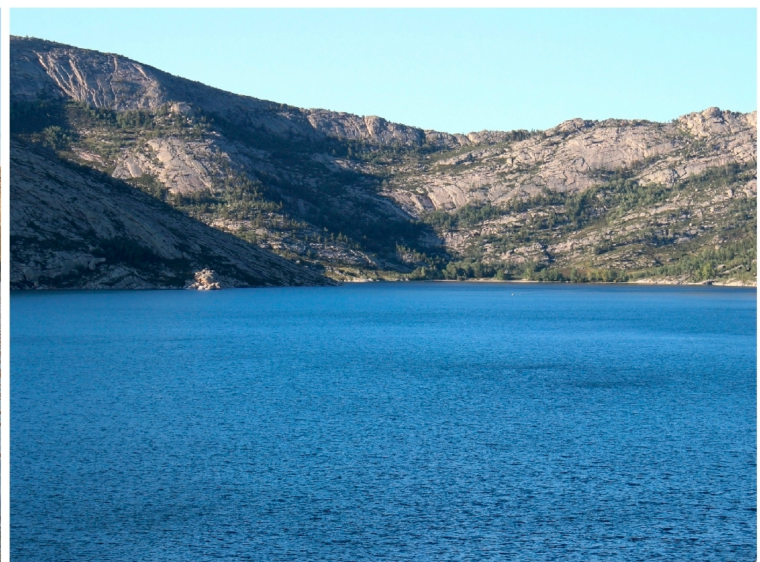

B

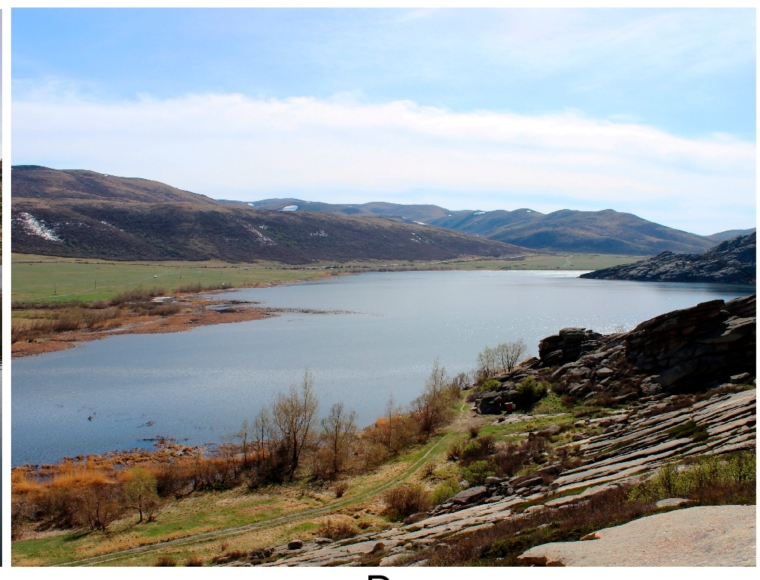

D

Figure 3. Geomorphic setting of the Sibe lakes in the Koktau Mountain foothills formed by the tectonically uplifted granitic bedrock. (A) Lake Sadyrkol; (B) Lake Tortkara; (C) Lake Shalkar; (D) Lake Korzhynkol (photographs by A.B. Myrzagalieva and J. Chlachula).

\subsection{The Sibe Lakes' Hydrology and Hydrogeology}

The cumulative Sibe lakes' area is $\sim 31 \mathrm{~km}^{2}$ with a total water volume $\sim 84.3 \mathrm{mil} . \mathrm{m}^{3}$. The depth of the lacustrine basins is $2-48 \mathrm{~m}$ (own 2018 bathymetry measurements: $19 \mathrm{~m}$ Korzhynkol, $51 \mathrm{~m}$ Shalkar), with water transparency in the reservoirs 6-7 $\mathrm{m}$ in average. Lake Shalkar, as the deepest and the largest of the lakes, has a size of 251 ha and up to $-11 \mathrm{~m}$ clear water limits (Figure 2C). Hydrology of these groundwater-fed lake bodies is still not fully understood. Deep aquafiers presumably pass through the underground morphostructural fissures within the igneous bedrock, representing the regional geological base [38], and the mantling loose sandy-gravel deposits forming the bottom part of the basins. External water supply is primarily from the spring snowmelt. There are minor seasonal inlet streams into the lakes from the surrounding hills with the major sewerage influx in late spring (May).

Two annual precipitation peaks in March and August $(102 \mathrm{~mm}$ and $85 \mathrm{~mm}$, respectively) add to the temporary top ground saturation and the lake level rise, reaching the maximum stand in April-May [74], and gradually dropping during the following summer 
months (June-July). There is no external drainage from the lakes which are hydrologically closed, i.e., without an outlet, except for minor seasonal outflows. The lakes are drained between each other by an interconnecting small (no-name) stream. The average water capacity of the stream is $<0.5 \mathrm{~m}^{3} / \mathrm{s}$ gradually reduced after the spring snowmelt and the summer (August) rains towards the low-level lake stands in fall (October-November). From December to March, the lakes are solidly frozen and the levels are stable.

\section{Aims, Material and Methods}

The aims of the investigations were to document the complexity of hydrochemical and hydrobiological characteristics of the Sibe lakes in terms of their biocenosis structure (biotic diversity) and environmental dynamics. The focus was on zooplankton determining the trophic relations of the lake system, the lake's productivity as well as the corresponding water quality. The applied research goal was to assess the role of the local biocenosis diversity in terms of the macrozoobenthos taxonomy on natural functioning of the solitary lakes as sources of drinking water and the overall biomass productivity for sustainable fishery industry and sportive fishing.

Following the previous pilot hydrochemistry and geoenvironmental studies and biocenosis monitoring (2014-2017), the systematic collecting of the diagnostic organic and inorganic material was carried out during the summer season (2019) from the Sadyrkol, Tortkara, Shalkar, Korzhynkol lakes, which correspond to the peak prolificacy of aquatic invertebrates (average July temperature $+20.8^{\circ} \mathrm{C}$ ). In winter, the zoobenthos activity is significantly slowed down since the lakes are covered by ice (average January temperature $-20.6{ }^{\circ} \mathrm{C}$ ). The samples were collected consecutively at the same locations. Water samples for hydrochemical and biological analyses were taken, 8 samples from each lake were taken from the surface water layer, the pelagial and littoral zones using the SP-2 sampling system.

Determination of the water oxygen content was carried out on site with the MAPK302E dissolved oxygen analyzer; the $\mathrm{pH}$ value was measured using the MAPK-901 $\mathrm{pH}$ meter. Geochemistry studies and water sampling were done according to standard procedures $[75,76]$. The hydrochemical analyzes were carried out in the state analytical "Laboratory-Atmosphere" LLP, Ust'-Kamenogorsk. The tests were carried out in accordance with the regulatory requirements [77]. The quality of surface waters in the littoral part of the lakes was assessed by using the Woodiwiss biotic index [78]. Quantitative data [79] covered all lacustrine biotopes. Zooplankton samples were taken in the shoreline zone by filtering 100 litres of water through the Apstein net at depths of $>2 \mathrm{~m}$ throughout the water column with a small Jedi net from mill gas no. 55. The field samples were fixed by $40 \%$ formalin solution and subsequently analyzed in the laboratory.

The following parameters were examined:

- $\quad$ species taxonomy composition;

- $\quad$ total size of the biotic community;

- total biomass;

- biomass composition of dominant groups and species;

- zonal quantitative and qualitative zooplankton distribution.

The zooplankton taxonomy [80-84] was identified by using the MBS-10, "Biolam" microscope. When calculating the individual weight of zooplankton the equations of the linear-weight dependence were used. For each Crustacea species, the abundance and weight of the particular development stages were summed up. The abundance and mass of zooplankton were calculated per $1 \mathrm{~m}^{3}$ of the water column [85]. The biocenosis structure of the individual lakes was compared using the Jaccard coefficient [86] as the proximity indicator of the zooplankton community taxonomic composition. This analysis is routinely performed at other lakes so the results can be comparatively treated within the regional lakes' biocenosis study.

The zoobenthos samples were taken using the Petersen sampler with a capture area of $0.025 \mathrm{~m}^{2}$. The samples were washed on a mill gas sieve (no. 23) to remove fine sediments. Living organisms were separated and placed into labelled plastic or glass containers, after 
which the samples were fixed with a $4 \%$ formaldehyde solution for species taxonomic identification [87-89]. The zooplankton microorganisms were microscope-counted and weighed by the electronic balance with a resolution of $0.001 \mathrm{~g}$, invertebrates with a weight resolution of $0.01 \mathrm{~g}$. The obtained data on the zooplankton frequencies and biomass in each sample were extrapolated to $1 \mathrm{~m}^{2}$.

The overall biotic productivity of water bodies was determined according to the trophicity scale [90].The water quality of the Sibe Lakes in terms of zooplankton parameters was determined by using the Pantle and Bukka saprobity indexes modified by [91]. The species composition is expressed by the counted ratio of the total number of species in the biocenosis to the number of individuals (abundance or biomass) [92]. The Shannon Species Diversity Index (SSDI) was used for the assessment of the degree of the biocenoses diversity and complexity [93]. The quality of surface waters in the littoral part of the lakes was determined by the Woodiwiss biotic index [78]. The analytical classification of the hydrochemical types of the lake waters refers to the definition of SzczukariewPrikłoński [94].

\section{Results}

\subsection{Lake Hydrochemistry}

Hydrochemistry of the lakes shows some minor variations in the chemical elements in spite of the proximity of the basins (Table 1). During the sampling period (2019), the water temperature in the lakes was $23.3-25.9^{\circ} \mathrm{C}$. The waters were characterized by high transparency with little colour. The $\mathrm{pH}$ value, as one of the important indicators determining the ratio of ions in water and the direction of chemical processes in the lakes, varied within a narrow range averaged 9.13. In terms of the $\mathrm{pH}$ value, the lakes are classified as alkaline.

The nature of the $\mathrm{pH}$ change is closely interrelated with the carbon dioxide equilibrium $\mathrm{H}_{2} \mathrm{CO}_{3} \leftrightarrow \mathrm{H}^{+}+\mathrm{HCO}_{3}^{-} \leftrightarrow 2 \mathrm{H}^{+}+\mathrm{CO}_{3}^{2-}$ which is determined by the concentration of bicarbonate ions and carbonates. In an alkaline medium, the content of the bicarbonate ions is $90 \%$, which corresponds to the obtained data of the Sibe lakes system. The content of bicarbonate ions ranged from $\sim 126-127 \mathrm{mg} / \mathrm{dm}^{3}$ (Lake Shalkar and Korzhynkol) to $137.5 \mathrm{mg} / \mathrm{dm}^{3}$ (Lake Sadyrkol). The content of carbonate ions $\left(\mathrm{CO}_{2}\right)$ varied from $9.0 \mathrm{mg} / \mathrm{dm}^{3}$ (Lake Korzhynkol) to $15.0 \mathrm{mg} / \mathrm{dm}^{3}$ (Lake Sadyrkol). According to the applied classification [76,94], the waters of the Sadyrkol, Torkara, Shalkar and Korzhynkol lakes belong to the hydrocarbonate-calcium class and the first type in terms of the total ratio of ions. Lake Sadyrkol and Lake Tortkara are characterized by the bicarbonate-calcium-magnesium type $\left(\mathrm{HCO}_{3}{ }^{-}-\mathrm{Ca}^{2+}-\mathrm{Mg}^{2}\right)$, Lake Korzhynkol by the bicarbonate-calcium-sodium type $\left(\mathrm{HCO}_{3}{ }^{-}-\mathrm{Ca}^{2+}-\mathrm{Na}^{+}\right)$, and Lake Shalkar by the bicarbonate-calcium-magnesium-sodium type $\left(\mathrm{HCO}_{3}{ }^{-}-\mathrm{Ca}^{2+}-\mathrm{Mg}^{2}-\mathrm{Na}^{+}\right)$(Figure 4$)$. The salinity of the lakes $\left(84.0 \mathrm{mg} / \mathrm{dm}^{3}\right.$, Lake Tortkara; $93.7 \mathrm{mg} / \mathrm{dm}^{3}$, Lake Shalkar) indicates fresh, slightly mineralized waters. In terms of hardness, the lake waters are very soft $\left(1.15-1.30 \mathrm{mg}\right.$-eq $\left./ \mathrm{dm}^{3}\right)$.

The content of dissolved oxygen was relatively uniform $\left(10.9-11.2 \mathrm{mg} / \mathrm{dm}^{3}\right)$ with Lake Shalkar most oxidized $\left(\sim 12.5 \mathrm{mg} / \mathrm{dm}^{3}\right)$. The oxygen content as the biotic productivity indicator of the aquatic ecosystems shows the overall favourable conditions of the lacustrine basins for organisms. The present oxygen regime along with permanganate oxidizability and water hydrochemistry ultimately determine the amount of organic matter in the reservoirs. The water permanganates ranged from $2.80 \mathrm{mg} / \mathrm{dm}^{3}$ (Lake Sadyrkol) to $3.61 \mathrm{mg} / \mathrm{dm}^{3}$ (Lake Shalkar), indicating a very low water oxidizability. Of the inorganic nitrogen-containing compounds, ammonium ions predominated in the water samples with the average concentrations ranging from $0.274 \mathrm{mg} / \mathrm{dm}^{3}$ (Lake Tortkara) to $0.375 \mathrm{mg} / \mathrm{dm}^{3}$ (Lake Shalkar).

The content of nitrates (nitrite and nitrate ions), as of the principal nutrients of aquatic vegetation, was below the detection limit at all sampling sites. Ammonium nitrogen $\left(\mathrm{NH}_{4}{ }^{+}\right)$ enters surface waters with atmospheric precipitation, as well as a result of the destruction of organic compounds. Its amount decreases during the period of rapid plant development. 
The concentration of the detected phosphate ions, which, along with nitrogen compounds, are biogenic substances that determine the quality of water, varied in a narrow range of $\sim 0.03-0.06 \mathrm{mg} / \mathrm{dm}^{3}$. The predominant anions were hydrocarbonate $\left(\mathrm{HCO}_{3}{ }^{-}\right)$ions; the content of sulphate ions varied from $22.6 \mathrm{mg} / \mathrm{dm}^{3}$ (Lake Tortkara) to $30.5 \mathrm{mg} / \mathrm{dm}^{3}$ (Lake Shalkar); the concentration of chlorides was 3.71-4.17 mg/ $\mathrm{dm}^{3}$ (Lake Korzhynkol) and $5.10-5.56 \mathrm{mg} / \mathrm{dm}^{3}$ (Lake Torkara, Shalkar, Korzhynkol). Of the cations, with a content of $\sim 14.5-18.0 \mathrm{mg} / \mathrm{dm}^{3}$, calcium ions dominated.

The concentration of sodium cations ranged from $5.68 \mathrm{mg} / \mathrm{dm}^{3}$ (Lake Tortkara) to $8.15 \mathrm{mg} / \mathrm{dm}^{3}$ (Lake Shalkar); the content of magnesium ions varied from $3.8 \mathrm{mg} / \mathrm{dm}^{3}$ (Lake Korzhynkol) to $5.4 \mathrm{mg} / \mathrm{dm}^{3}$ (Lake Sadyrkol and Tortkara) along with potassium ions $\left(2.18-3.66 \mathrm{mg} / \mathrm{dm}^{3}\right)$.

Overall, the hydrochemistry of the investigated lakes shows relatively high oxygen contents (maximum in Lake Shalkar), a medium alkalinity and a very low oxidation/oxidizability. The waters are fresh, clean and very soft in terms of hardness; they belong to the hydrocarbonate-calcium class. Lake Shalkar with the higher oxygen and mineral $(\mathrm{Ca}, \mathrm{Na}, \mathrm{K})$ contents theoretically provides best conditions for biological productivity. The high mineral status of this lake may result from specific hydrological conditions and the bedrock structure of this deepest $(-51 \mathrm{~m})$ lake. The depth of the intermontane basin filling a tectonic depression and cooler waters are the presumed contra-factors reducing the potential macrozoobenthos biomass to the present (actual) level.

\subsection{Zooplankton Ecology}

Zooplankton is one of the most important indicators of biotic productivity and health of the aquatic ecosystems [95]. Its composition, structure and the level of development determine the direction and intensity of matter and energy flows in watercourses and stagnant reservoirs. Zooplankton is one of the links in the food chain in the ecosystem including zoobenthos and fish food. The survival rate of fish juveniles, the fish growth rate, and, ultimately, the fish productivity all depends on the concentration of the zooplankton biomass [48].

The documented Sibe lakes zooplankton taxonomic composition (August 2019) revealed a total of 15 taxa, including Rotifera (1 species), Copepoda (4 species), Cladocera (10 species) (Table 2). Cladocera are the most represented in zooplankton, accounting for $67 \%$ of the taxa. Lake Korzhynkol shows the greatest diversity of zooplankton with Mesocyclops leuckarti, Diaphanosoma brachyurum, and Ceriodaphnia quadrangular as the dominant species. The similarity assessment (Jaccard's coefficient 25-38\%), shows low-to-moderate zooplankton taxonomic uniformity.

The saprobiological analysis showed the predominance of the $\beta$-saprobic species in the composition of zooplankton (most pronounced in Lake Shalkar and Lake Korzhynkol), which indicates a moderate natural pollution of the lakes' surface waters in corroboration with the Pantle-Bukk saprobity index (1.51-1.83). In sum, the lakes show some differences in the zooplankton, its spatial distribution as well as in total biomass (Tables 3 and 4; Figures 5 and 6).

Table 1. Hydrochemical characteristics (average values) of the Sibe lakes (August 2019) (S-Sadyrkol, T-Tortkara, ShShalkar, K-Korzhynkol). ${ }^{*}\left(\mathrm{mg} / \mathrm{dm}^{3}\right),{ }^{* *}\left(\mathrm{mg}-\mathrm{eq} / \mathrm{dm}^{3}\right),{ }^{* * *}\left(\mathrm{mgO} / \mathrm{dm}^{3}\right)$.

\begin{tabular}{|c|c|c|c|c|c|c|c|c|c|c|c|c|c|c|c|c|c|}
\hline $\begin{array}{l}n \\
\pm \\
1 \\
1\end{array}$ & $\begin{array}{l}* \\
\text { ปे }\end{array}$ & $\frac{T}{2}$ & 党 & $\begin{array}{l}\text { * } \\
1 \\
0^{\infty} \\
Z\end{array}$ & $\begin{array}{l}* \\
\text { it } \\
\text { On }\end{array}$ & 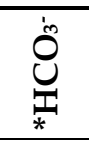 & के * & 芰 & נָ & 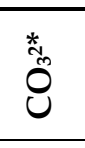 & 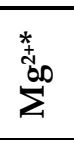 & $\stackrel{+}{+}$ & 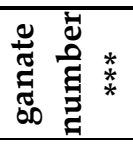 & $\begin{array}{l}\stackrel{*}{*}^{*} \\
\overbrace{}^{+} \\
\mathcal{W}^{\prime}\end{array}$ & 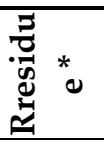 & $\begin{array}{l}x^{*} \\
0^{+} \\
0^{+}\end{array}$ & $\stackrel{*}{\dot{U}}$ \\
\hline$S$ & 10.93 & 9.13 & 0.297 & $<0.1$ & .0 & 137.5 & 1.20 & 2.40 & 14.8 & 15.0 & 5.4 & 5.99 & 2.8 & 25.2 & 85.0 & 0.039 & 5.33 \\
\hline T & .20 & 9.16 & 274 & $<0.1$ & $<0.007$ & 129.6 & 1.16 & 2.18 & $14.2 \mathrm{M}$ & 12.0 & 5.4 & 5.68 & 2.72 & 22.6 & 83.6 & 3 & 5.10 \\
\hline Sh & 12.47 & 9.08 & 0.375 & $<0.1$ & $<0.007$ & 127.3 & 1.27 & 3.66 & 16.5 & 12.0 & 5.3 & 8.15 & 3.61 & 30.5 & 92.8 & 0.055 & 5.10 \\
\hline $\mathbf{K}$ & 11.22 & 9.07 & 0.327 & $<0.1$ & $<0.007$ & 125.8 & 1.21 & 2.85 & 17.8 & 9.0 & 3.8 & 7.82 & 2.94 & 27.5 & 90.0 & 0.044 & 3.94 \\
\hline
\end{tabular}




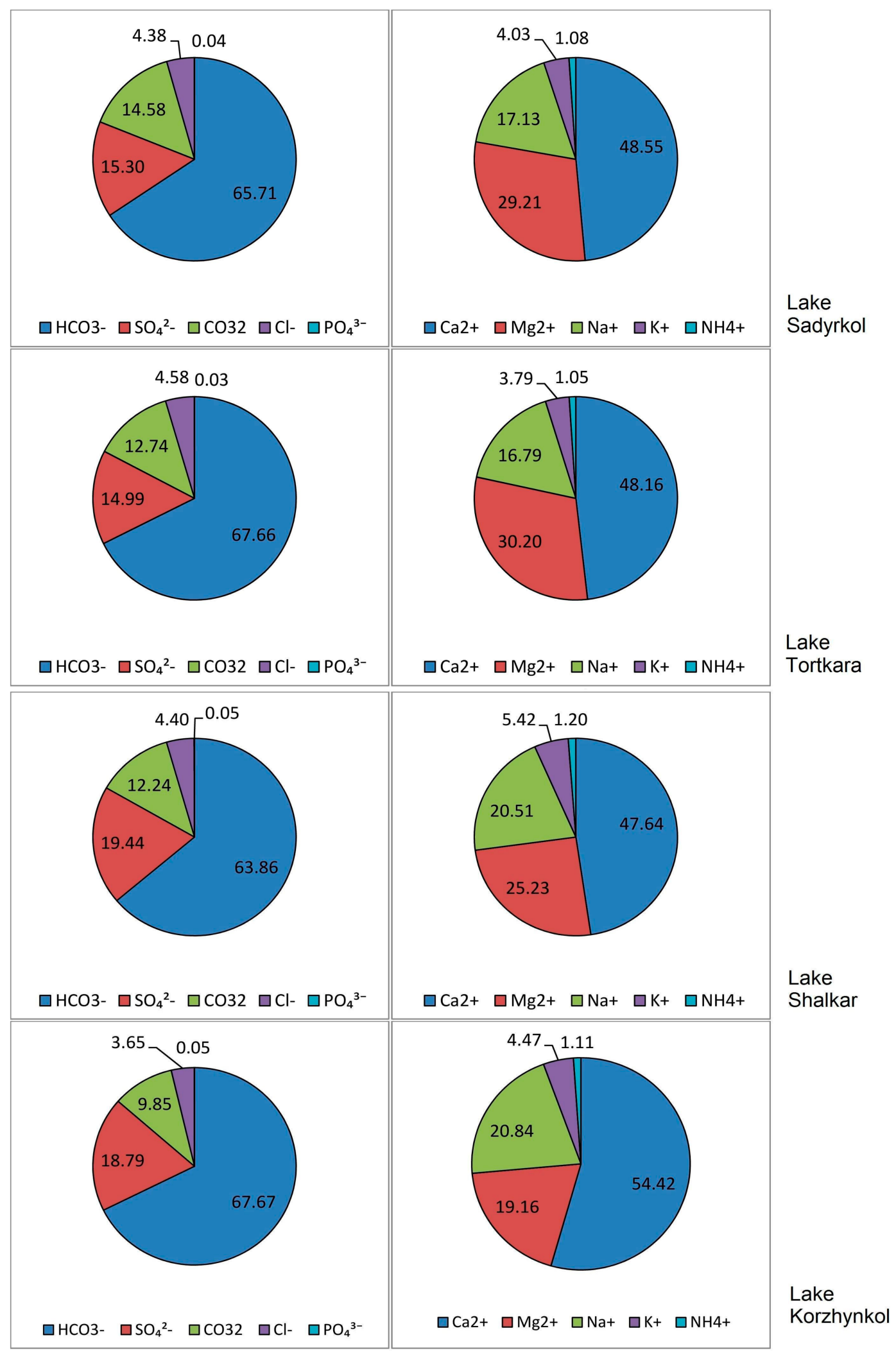

Figure 4. Geochemistry of the Sibe lakes. Ion balance (in \%) of the single basins, showing the proportions of anions and cations. The water type classification of Szczukariew-Prikłoński [94] is defined by those ions, concentration of which is $>20 \%$ (milligram equivalents per litre of a sample) based on the total sum of the anions or cations. The specific water type begins with the ion with the highest content in the lake waters. 
Table 2. Taxonomic composition, the degree of saprobity $(\mathrm{C} / \mathrm{s})$ and the frequencyof occurrence (\%) of zooplankton of the Sibe lakes' system (August 2019).

\begin{tabular}{|c|c|c|c|c|c|}
\hline \multirow{2}{*}{ Taxon } & \multirow{2}{*}{$\mathrm{D} / \mathrm{s}$} & \multicolumn{4}{|c|}{ Frequency of Occurrence (\%) } \\
\hline & & Sadyrkol & Tortkara & Shalkar & Korzhynkol \\
\hline \multicolumn{6}{|l|}{ Rotifera } \\
\hline Keratella cochlearis (Gosse) & $\beta-o$ & - & - & - & 50 \\
\hline \multicolumn{6}{|l|}{ Copepoda } \\
\hline Eudiaptomus sp. & - & - & 50 & - & - \\
\hline Acanthocyclops sp. & - & - & 50 & - & 100 \\
\hline Cyclops vicinus (Uljanine) & $\beta$ & - & 50 & - & 100 \\
\hline Mesocyclops leuckarti (Claus) & $\mathrm{o}$ & 100 & 50 & 50 & 50 \\
\hline \multicolumn{6}{|l|}{ Cladocera } \\
\hline Diaphanosoma brachyurum (Lievin) & $0-\beta$ & - & 50 & 50 & 100 \\
\hline Ceriodaphnia quadrangula (Muller) & $\beta$ & 100 & 50 & - & 50 \\
\hline Bosmina longirostris (Muller) & $0-\beta$ & - & - & 50 & 50 \\
\hline Bosmina longispina (Leydig) & $\beta$ & - & - & - & 50 \\
\hline Daphnia longispina (Muller) & $\beta$ & 50 & - & 100 & 50 \\
\hline Daphnia cucullata (Sars) & $\beta$ & - & - & 50 & 50 \\
\hline Pleuroxus sp. & - & - & - & - & 50 \\
\hline Chydorus sphaericus(Muller) & $\beta$ & - & - & 50 & - \\
\hline Alona rectangular (Sars) & $\mathrm{O}$ & - & - & 50 & - \\
\hline Simocephalus vetulus (Muller) & $0-\beta$ & 50 & 50 & 50 & - \\
\hline Total nubmers/species richness & & 4 & 7 & 8 & 11 \\
\hline
\end{tabular}

Note: D/s-the degree of saprobity.

\section{Lake Sadyrkol}

In the composition of the zooplankton of Lake Sadyrkol, 4 taxa of invertebrates were identified. Zooplankton is characterized as cladocero-copepod. The average number of invertebrates was 21.7 ind. $/ \mathrm{m}^{2}$, average biomass $564 \mathrm{mg} / \mathrm{m}^{3}$, which corresponds to a freshwater reservoir of the $\beta$-oligotrophic type with a very low trophicity (Tables 3 and 4 ). Copepods of $M$. leuckarti dominated in the pelagial zone in terms of abundance and biomass, while in the littoral zone, cladocerans of Daphnia longispina contributed (80\%) to the bulk of the biomass. The high zooplankton biomass in the lake's coastal zone is explained by the massive organism development (Cladocera) of the Daphnia longispina species, while small cladocerans (Ceriodaphnia quadrangular) $\left(14.0\right.$ ind. $\left./ \mathrm{m}^{2}\right)$ dominate quantitatively.

\section{Lake Tortkara}

Seven invertebrate taxa were found in the zooplankton of Lake Tortkara, (Table 2). The littoral part showed very low zooplankton diversity with only one species (Cyclops vicinus) found in the samples. In the pelagial zone, the number of invertebrates was $3.42 \mathrm{ind} . / \mathrm{m}^{2}$, and average biomass $128 \mathrm{mg} / \mathrm{m}^{3}$ (Tables 3 and 4). The biomass of copepods (Copepoda) and cladocera (Cladocera) was almost the same. The level of zooplankton development was low; the lake corresponds to the $\alpha$-oligotrophic type of a very low trophicity.

\section{Lake Shalkar}

Eight zooplankton taxa were recorded in Lake Shalkar (Table 2). The average amount of zooplankton was 15.48 ind. $/ \mathrm{m}^{3}$, average biomass $1189 \mathrm{mg} / \mathrm{m}^{3}$, which corresponds to a reservoir of a moderate trophicity (Tables 3 and 4 ). In the pelagic zone, cladocerans were the most abundant. The share of cladocera biomass was $96 \%$. In the coastal zone, zooplankton communities were characterized as cladoceran. The population of all cladocerans was almost at the same level with Daphnia longispina (32\%) and Simocephalus vetulus (49\%), being the prevailing zooplankton species. 


\section{Lake Korzhynkol}

Higher zooplankton diversity with 11 taxa of moderate trophicity water was detected in Lake Korzhynkol (Table 2). Abundance of zooplankton is 57.86 thousand ind. $/ \mathrm{m}^{3}$ and average biomass $1107 \mathrm{mg} / \mathrm{m}^{3}$ (Tables 3 and 4). The biomass frequency in the littoral zone is twice of the pelagial zone. Near the lake shore, the biomass was largely composed by copepods (Copepoda); in the pelagic zone by cladocerans (Cladocera), particularly by Diaphanosoma brachyurum and Ceriodaphnia quadrangula.

Table 3. Values of abundance (thousand ind. $/ \mathrm{m}^{3}$ ) of zooplankton.

\begin{tabular}{ccccccccc}
\hline \multirow{2}{*}{$\begin{array}{c}\text { Zooplankton } \\
\text { Category/Zone }\end{array}$} & \multicolumn{2}{c}{ Sadyrkol } & \multicolumn{2}{c}{ Tortkara } & \multicolumn{2}{c}{ Shalkar } & \multicolumn{2}{c}{ Korzhynkol } \\
\cline { 2 - 9 } & Littoral & Pelagial & Littoral & Pelagial & Littoral & Pelagial & Littoral & Pelagial \\
\hline Rotifera & - & - & - & - & - & - & 4.8 & - \\
Copepoda & 27.3 & 3.5 & 1.19 & 2.31 & - & 3.74 & 73.2 & $11.01-$ \\
Cladocera & 21.7 & 1.6 & - & 1.11 & 9.15 & 14.33 & 17.1 & 7.96 \\
\hline Total & 49.0 & 5.1 & 1.19 & 3.42 & 9.15 & 18.07 & 95.1 & 18.97 \\
\hline
\end{tabular}

Table 4. Values of biomass $\left(\mathrm{mg} / \mathrm{m}^{3}\right)$ of zooplankton.

\begin{tabular}{ccccccccc}
\hline \multirow{2}{*}{$\begin{array}{c}\text { Zooplankton } \\
\text { Category/Zone }\end{array}$} & \multicolumn{2}{c}{ Sadyrkol } & \multicolumn{2}{c}{ Tortkara } & \multicolumn{2}{c}{ Shalkar } & \multicolumn{2}{c}{ Korzhynkol } \\
\cline { 2 - 9 } & Littoral & Pelagial & Littoral & Pelagial & Littoral & Pelagial & Littoral & Pelagial \\
\hline Rotifera & - & - & - & - & - & - & 6 & - \\
Copepoda & 274 & 123 & 119 & 62 & - & 62 & 915 & 180 \\
Cladocera & 627 & 102 & - & 66 & 722 & 1531 & 610 & 496 \\
\hline Total & 901 & 225 & 119 & 128 & 722 & 1593 & 1531 & 676 \\
\hline
\end{tabular}

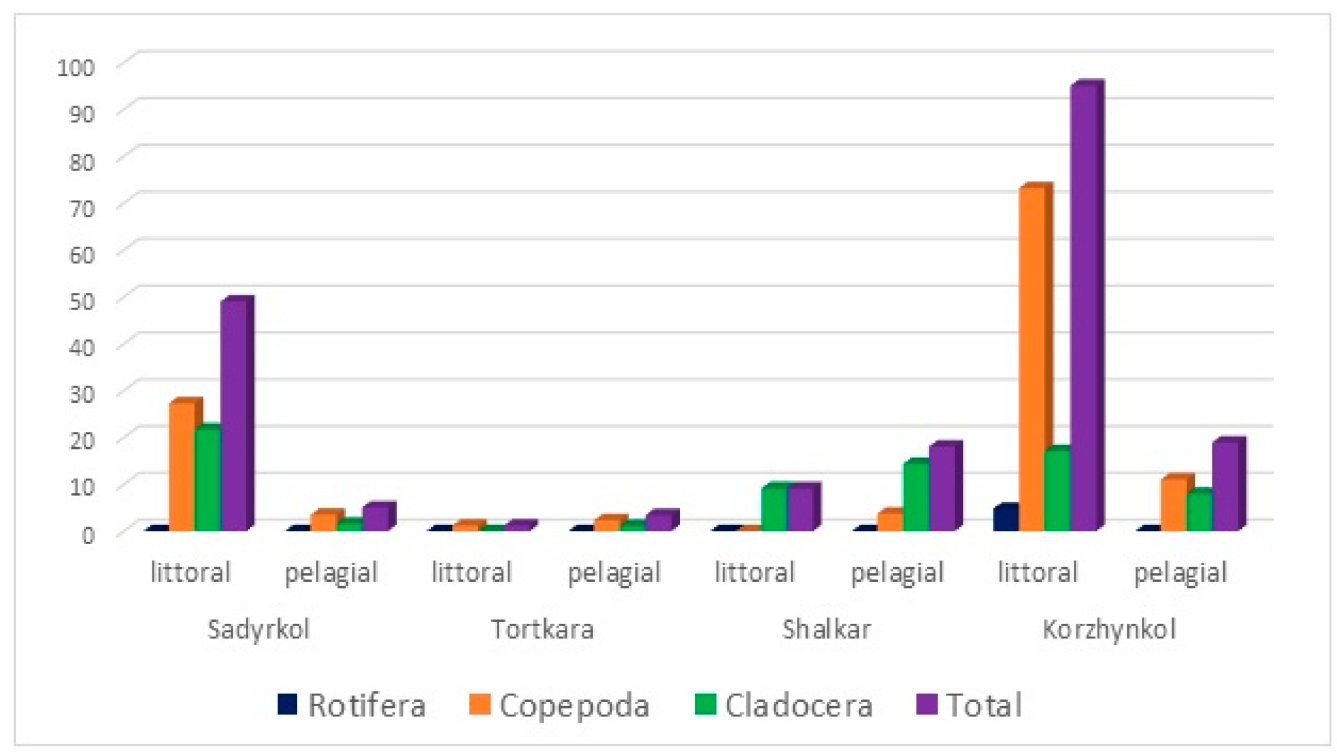

Figure 5. Quantitative representation (thousand ind. $/ \mathrm{m}^{3}$ ) of zooplankton in the Sibe lakes. 


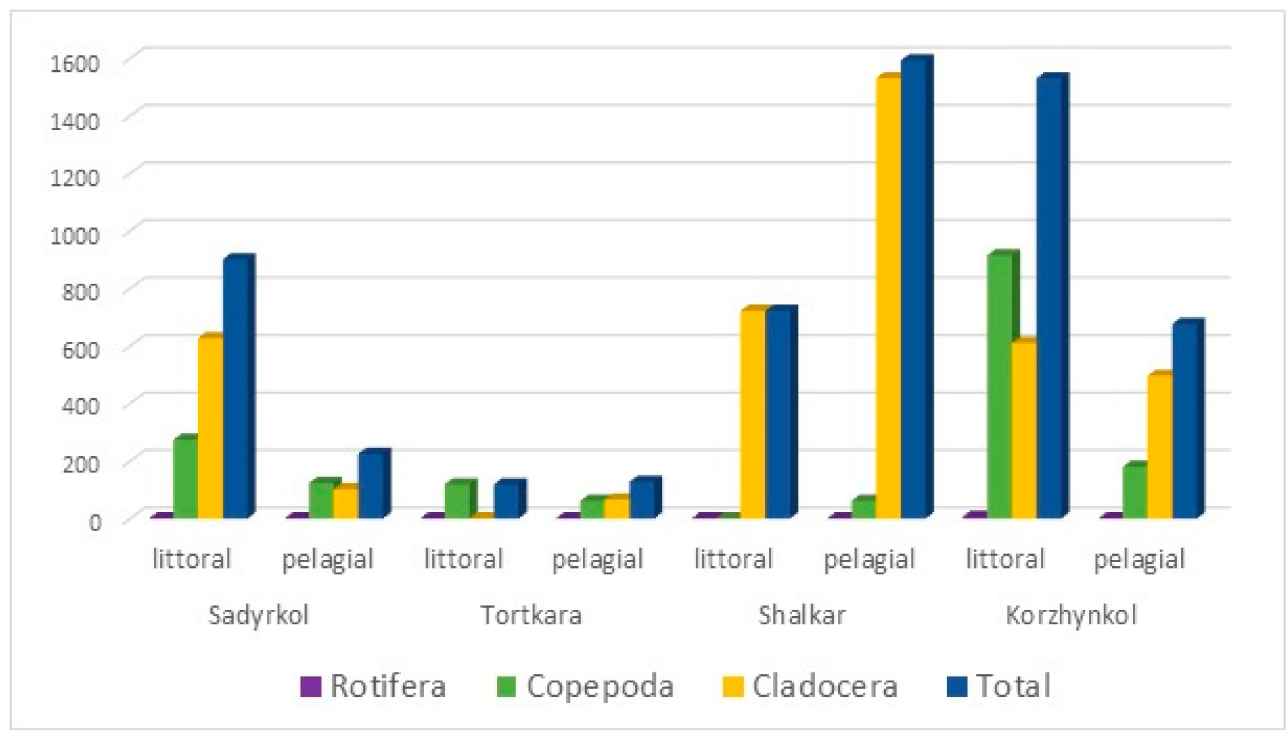

Figure 6. Abundance $\left(\mathrm{mg} / \mathrm{m}^{3}\right)$ of the zooplankton biomass in the Sibe lakes.

\subsection{Macrozoobenthos Ecology}

Zoobenthos serves as an excellent indicator of biochemical processes occurring in the water reservoir caused by anthropogenic and/or natural factors and represent a parameter of possible environmental degradation/environmental quality element [96-98]. The Sibe macrozoobenthos community composition in the single lakes shows (Tables 5 and 6) dependence on the species richness and the total abundance of the lake benthic invertebrate fauna biomass [92] on the specific environmental conditions.

Table 5. Average values of the main macrozoobenthos indicators of the Sibe lakes (2019).

\begin{tabular}{ccccc}
\hline Sibe Lakes & $\begin{array}{c}\text { Shannon } \\
\text { Index }\end{array}$ & $\begin{array}{c}\text { Uniformity } \\
\text { Index }\end{array}$ & $\begin{array}{c}\text { Biotic Littoral } \\
\text { Index }\end{array}$ & Water Quality Class \\
\hline Lake Sadyrkol & $2.61 \pm 0.11$ & $0.52 \pm 0.13$ & 9 & II (clean) \\
Lake Tortkara & $2.38 \pm 0.19$ & $0.43 \pm 0.02$ & 7 & II (clean) \\
Lake Shalkar & $2.09 \pm 0.22$ & $0.40 \pm 0.04$ & 6 & III (slightly polluted) \\
Lake Korzhynkol & $1.94 \pm 0.05$ & $0.58 \pm 0.14$ & 8 & II (clean) \\
\hline
\end{tabular}

A presumed factor in the macrozoobenthos variation is a differential presence of ichthyofauna selectively feeding (in terms of the particular most common fish speciesCyprinus carpio, Coregonus albulaladogensis, Carassius rutilus) on the lakes' biomass.

The taxonomic structure of the macrozoobenthos of the Sibe lacustrine system is classed into 4 groups including a total of 37 macro-invertebrate taxa: 13 chironomid larvae (Chironomidae), 8 molluscs, 3 mayfly larvae (Ephemeroptera), 3 beetles (Coleoptera) and 3 dragonflies (Odonata), 1 species of amphipods (Amphipoda), ticks (Hydrachnidia), leeches (Hirudinea), gammarus (Gammarus), caddis flies (Trichoptera), biting midges (Ceratopogonidae) and flyflies (Megaloptera). The molluscs Anisus vortex A. dispar and chironomid larvae Chironomus plumosus had the highest frequency of occurrence (a total of $84 \%$ of all macro-organisms) (Figure 7). Rare and endemic species play an important role in the biocenoses of the Sibe lakes. They increase the small aquatic fauna taxonomic variety and contrite to macrozoobenthos stability under the changing aquatic conditions. Among these, 17 invertebrate taxa (12\% of the total biocenosis structure) include molluscs (Mollusca), dragonfly larvae (Odonata), dipterans (Diptera) and mayflies (Ephemeroptera). 
Table 6. Littoral and pelagial zones' aquatic biotic community parameters: (A) abundance (ind. $/ \mathrm{m}^{3}$ ) and (B) total biomass $\left(\mathrm{g} / \mathrm{m}^{3}\right)$ of the benthic biotopes of the Sibe lakes.

\begin{tabular}{|c|c|c|c|c|c|c|c|c|c|c|c|c|c|c|c|c|}
\hline \multirow{3}{*}{ Benthos Group } & \multicolumn{4}{|c|}{ Lake Sadyrkol } & \multicolumn{4}{|c|}{ Lake Tortkara } & \multicolumn{4}{|c|}{ Lake Shalkar } & \multicolumn{4}{|c|}{ Lake Korzhynkol } \\
\hline & \multicolumn{2}{|c|}{ Littoral } & \multicolumn{2}{|c|}{ Pelagial } & \multicolumn{2}{|c|}{ Littoral } & \multicolumn{2}{|c|}{ Pelagial } & \multicolumn{2}{|c|}{ Littoral } & \multicolumn{2}{|c|}{ Pelagial } & \multicolumn{2}{|c|}{ Littoral } & \multicolumn{2}{|c|}{ Pelagial } \\
\hline & A & B & A & B & A & B & A & B & A & B & A & B & $\mathbf{P}$ & B & $\mathbf{P}$ & B \\
\hline Mollusca & 32.0 & 10.02 & 40 & 0.32 & 440 & 20.6 & 40 & 0.14 & 280 & 738 & 280 & 8.52 & 520 & 3.98 & 200 & 1.52 \\
\hline Larvae Odonata & 40 & 0.20 & - & - & - & - & 80 & 9.64 & - & - & - & - & 40 & 0.60 & - & - \\
\hline $\begin{array}{c}\text { Larvae } \\
\text { Ephemeroptera }\end{array}$ & 280 & 0.90 & - & - & - & - & 80 & 0.12 & - & - & - & - & 200 & 0.25 & - & - \\
\hline Larvae Trichoptera & & & - & - & - & - & 40 & 0.16 & - & - & - & - & 40 & 0.17 & - & - \\
\hline Larvae Coleoptera & 120 & 0.54 & - & - & - & - & 80 & 0.27 & - & - & - & - & 80 & 0.25 & - & - \\
\hline Gammaridae & 560 & 1.84 & - & - & - & - & - & - & - & - & 480 & 2.48 & 7120 & 22.21 & - & - \\
\hline $\begin{array}{c}\text { Larvae } \\
\text { Ceratopogonidae }\end{array}$ & & & - & - & - & - & 40 & 0.19 & - & - & - & - & - & - & - & - \\
\hline $\begin{array}{c}\text { Larvae } \\
\text { Chironomidae }\end{array}$ & 1400 & 8.24 & 200 & 1.28 & 120 & 0.96 & 280 & 0.53 & 520 & 16.36 & 480 & 3.36 & 160 & 0.44 & 40 & 0.52 \\
\hline Oligochaeta & 200 & 0.04 & - & - & - & - & 40 & 0.04 & 80 & 0.24 & - & - & - & - & - & - \\
\hline Hirudinea & 40 & 0.16 & - & - & - & - & - & - & - & - & - & - & - & - & - & - \\
\hline Sialidae & 40 & 1.28 & - & - & - & - & - & - & 40 & 0.28 & - & - & - & - & - & - \\
\hline Hydracarina & 200 & 0.28 & - & - & & & 40 & 0.14 & - & - & - & - & 40 & 0.08 & - & - \\
\hline Total & 3200 & 20.5 & 240 & 1.60 & 560 & 21.56 & 720 & 11.23 & 920 & 24.24 & 1240 & 14.37 & 8200 & 27.98 & 240 & 2.04 \\
\hline Trophic class & \multicolumn{2}{|c|}{ high } & \multicolumn{2}{|c|}{ low } & \multicolumn{2}{|c|}{ high } & \multicolumn{2}{|c|}{ increased } & \multicolumn{2}{|c|}{ high } & \multicolumn{2}{|c|}{ increased } & hi & & \multicolumn{2}{|c|}{ low } \\
\hline Lake average & \multicolumn{4}{|c|}{$\begin{array}{l}\text { A-1720 } \\
\text { B-11.05 }\end{array}$} & \multicolumn{4}{|c|}{$\begin{array}{l}\text { A-640 } \\
\text { B-16.40 }\end{array}$} & \multicolumn{4}{|c|}{$\begin{array}{l}\text { A-1080 } \\
\text { B-19.31 }\end{array}$} & \multicolumn{4}{|c|}{$\begin{array}{l}A-4220 \\
B-15.01\end{array}$} \\
\hline Trophic class & \multicolumn{4}{|c|}{ increased } & \multicolumn{4}{|c|}{ increased } & \multicolumn{4}{|c|}{ increased } & \multicolumn{4}{|c|}{ increased } \\
\hline
\end{tabular}

The degree of the biocenosis diversity and complexity assessed by the SSDI [99] and the uniformity index does not vary significantly between the single lakes. The maximum biocenosis diversity was found in Lake Sadyrkol (19 taxa) (Table 5), the minimum species varieties were recorded in Lake Sadyrkol and Korzhynkol (a total of 13 taxa in each lake). A significant difference in the taxonomic composition was documented in the littoral zone as well as in the deep-water (pelagial) zone. Alongside the sub-aquatic lake shores on the submerged sandy-gravel soils, the representatives of all taxonomic fauna groups were found (Table 6). At the bottom of the lakes in black silty sediment and organic detritus, only some molluscs and chironomid larvae were detected.

In terms of the lakes' biocenosis structure, the Jaccard index varies from 17 to $35 \%$ (Figure 8). The recorded maximum (moderate-degree) similarity is observed in the macrozoobenthos of the Lakes Tortkara-Sadyrkol and the Lakes Sadyrkol-Shalkar. Other Sibe lakes show a minor biocenosis similarity (with the Jaccard coefficient 17-26\%), indicating specific environmental parameters and a high level of autonomous functioning of the individual lacustrine basins. The analytical results point out that the formation and existence of solitary biocenoses in the Sibe lakes occur separately and independently in each lake, in spite of their nearest geographical proximity. This finding provides novel evidence of the closed lakes' autonomous behaviour in the semi-desert and arid steppe zone of East Kazakhstan. 


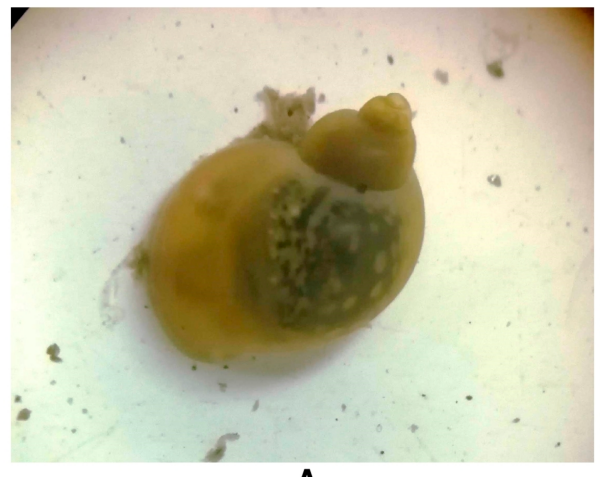

A

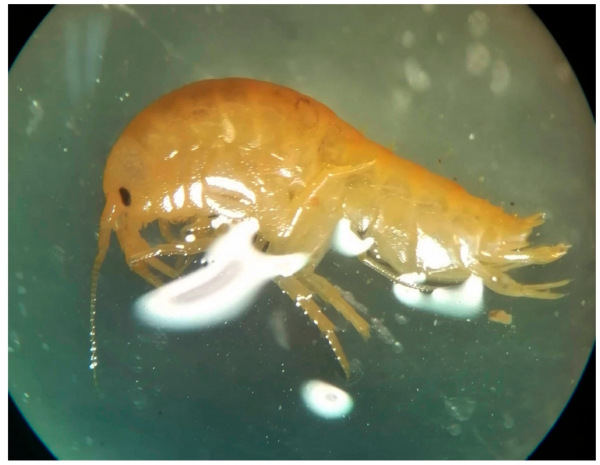

C

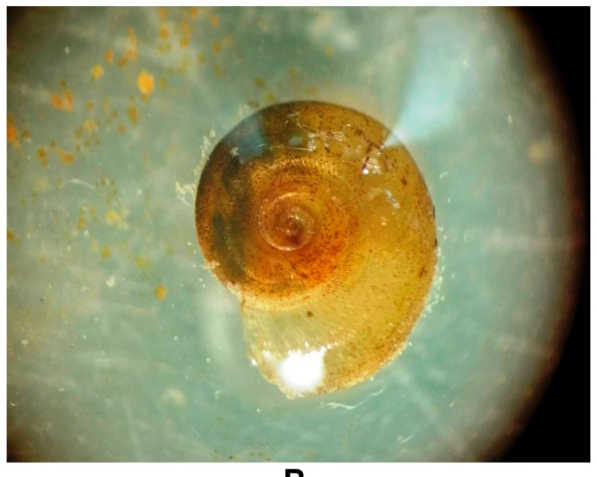

B

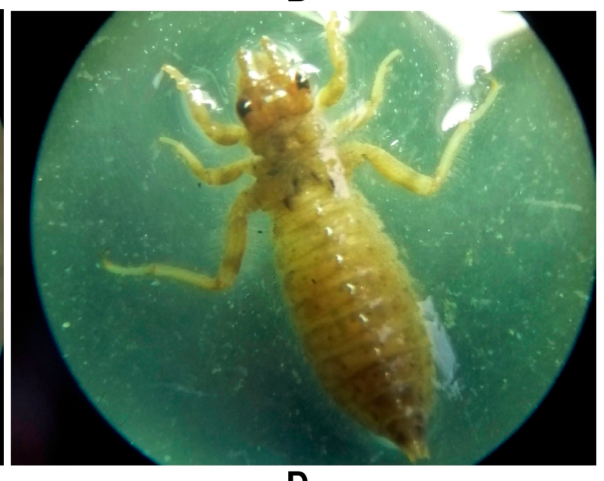

D

Figure 7. Macrozoobenthos of the Sibe Lakes: (A) Lymnaeaauricularia (Linnaeus, 1758), holarctic species; (B) Anisusdispar (Westerlund, 1871); (C) Gmelinoides sp.; (D) Corduliaaenaeturfosa Forster (larval stage). Optical microscope magnification (A,C) $20 \times$; (B) $30 \times$; (D) $10 \times$.

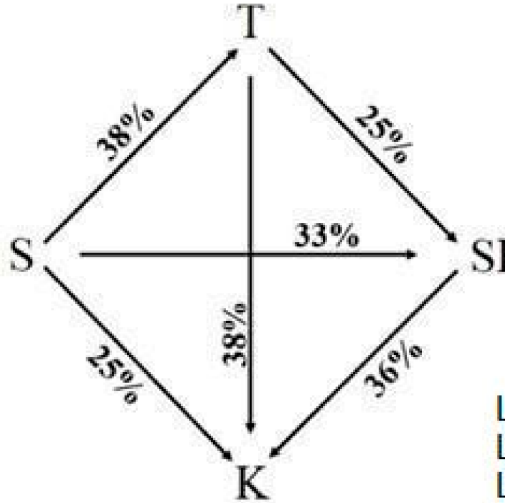

A

Figure 8. (A) Coefficient of similarity of the Jaccard test for the taxonomic composition of zooplankton of the Sibe lakes; (B) Coefficient values for the Sibe lakes' system.

\section{Résumé and Discussion}

\subsection{The Sibe Lakes' Biodiversity and Ecology Status}

The Sibe lakes, which represent unique natural freshwater reservoirs in the arid zone of East Kazakhstan, show a relatively high variability in the aquatic biocenosis in spite of the similar geoenvironmental-hydrochemical conditions, and the same geographic location and the geomorphic position. The geochemical imprint in the lake waters reflects the site's geological and geoenvironmental conditions. The spring snowmelt rich in dissolved minerals and the seasonal in-charge of the high-stand Taldybulak River to the Lake Korzhynkol, along with the groundwater seepage through the top soil/surface layers and high-summer 
evaporation are believed to account for the increased chemical element and bicarbonate concentrations in the lake water system.

The lake waters are oligotrophic (Sadyrkol and Tortkara) to moderately trophic (Shalkar and Korzhynkol).According to the status of the zooplankton development, Lake Sadyrkol corresponds to a $\beta$-oligotrophic type water basin, Lake Tortkara to $\alpha$-oligotrophic type water basin, both with a very low trophicity. The oligotrophy of the former lakes reflects the low nutrient, clean waters with a minor input of the terrestrial organic matter from the terrestrial settings of the mountain surroundings into the basins by perennial seasonal (spring) snowmelt streams, and indicate barren granitic rocky, and clastic sedimentary (sandy and gravelly) humus-free lake bottoms. With respect to the progressing macrozoobenthos proliferation in the littoral zone of the latter lakes (mainly Lake Korzhynkol), the increased trophicity within the nutrient-richer aquatic milieu is favourable for the local ichthyofauna development, promotes fishing, and thus enhances the Sibe lakes' sustainable use and the recreational potential.

The analysis of quantitative indicators of the macrozoobenthos formation shows that the benthic invertebrates are distributed extremely unevenly in the studied water bodies. This may partly reflect specific hydraulic conditions in each of the lakes as the geological base is lithologically uniform. The maximum species abundance and the total biomass were recorded in the littoral part of Lake Korzhynkol $\left(8200 \mathrm{ind} . / \mathrm{m}^{2}\right.$ and $27.98 \mathrm{~g} / \mathrm{m}^{2}$, respectively) (Table 6), which corresponded to the higher trophicity class [90]. The minima indicators of the quantitative development of macrozoobenthos and biomass were found in the deep-water zone of Lake Sadyrkol and Korzhynkol (240 ind. $/ \mathrm{m}^{2}$ and $1.60-2.04$ $\mathrm{g} / \mathrm{m}^{2}$, respectively). Both lakes exhibit a rather poor biocenosis structure dominated, at the former, by chironomid larvae ( $80 \%$ of the biomass) and, at the latter, by molluscs ( $75 \%$ of the biomass).

The inlets-outlets streams in conjunction with the other environmental factors may also account for the observed geochemical element and biological (including biomass production) differences among the Sibe lakes, as well as a likely intrusion of allochtonous abiotic terrigenous materials to the lake systems affecting metabolism of the lakes' biota.

The quality waters in the littoral part of the lakes by the Woodiwiss biotic index (WBI) was proven to be the best in the lakes Tortkara, Sadyrkol and Korzhynkol (WBI 7-9), which corresponds to the Class II of water quality (clean). Somewhat worse water parameters in Lake Shalkar (WBI 6; Class III of water quality) document a moderate (natural) pollution by fine sediments and organics, which may relate to water turbidity, among other potential causes.

The present findings suggest major differences in the lake development of the arid/ mountain zone of East Kazakhstan and variations (long-term as well as seasonal) in trophicity, and the saprobiological and phytoplankton dynamics $[99,100]$. There is no possibility of a closer comparison with other lake basis in the broader area in the absence of field research data. The only well-studied basins in SE Kazakhstan (the Kolsay Lakes in the Alatau Mountains) display a progressing eutrophication due to changes in the zooplankton structure triggered by deteriorating ecological conditions generated by both natural and environmental factors [101-103].

Yet, the current results from the Sibe lakes point that: (1) the contrasting abiotic environments, even at a very local spatial scale, can result in a specific structure of biological communities, and (2) the biocenosis species taxonomy differences on the level of genera may significantly influence the lake functioning because of a turnover among the equivalent macrozoobenthos species and their overall effects on the aquatic ecosystems. A feedback of aquatic flora on the zooplankton composition [104] is a separate study issue.

Regular zoo- and phytoplankton monitoring of the Sibe lakes will provide most valuable record for the regional aquatic ecosystems' change-assessment and littoral-terrestrialzone interactions within the NE Kazakhstan semi-arid steppe zone severely affected by the current aridification process observed across Central Asia [2,105,106]. The analogous small-scale lacustrine basins (both freshwater and brackish/saline) are most sensitive to 
ongoing environmental shifts with presently a minimum human disturbance observed in freshwater lakes across the broader territory [24].

The continuing investigations at the site will provide more accurate estimates and a multi-proxy evaluation of the ecosystem dynamics of the Sibe lakes. Complex studies of the relationship of the local aquatic flora and fauna, and the zooplankton structure will add to understanding of the biotic community functioning in the relation to the surrounding terrestrial environment and the possible climate change effects on the lake's ecology.

\subsection{The Sibe Lakes' Sustainable Use}

Except for the biodiversity values in terms of a pristine natural site, the Sibe lakes play an important role in the regional eco- and geo-tourism tourism and recreation [34-36] accentuated by the mosaic regional landscape diversity [37]. The documented zooplankton and macro-invertebrate diversity have a direct bearing to fishing, clean waters and other environmental aspects, which underline the regional importance for the Sibe lakes' system. Although the lakes are the popular places with about 5000-8000 visitors per year, mostly during the summer season, this does not constitute any noticeable harm to the lake settings, the water quality, as well as the lakes' surroundings. There are about 1500 inhabitants with cottages on the eastern bank of the Lake Tortkara, some of them practicing sportive fishing without a direct effect on the populations of the fish stocks. The principal fish species include roach (Rutilus rutilus), perch (Perca fluviatilis)), dace (Leuciscus leuciscus), tench (Tinca tinca), and pike (Esox lucius). In 1979, following an economic plan to create a lacustrine commercial fishery on the Sibe lakes, a carp (Cyprinus carpio) was introduced into the Lake Sadyrkol. In 1998, an re-establishment of the common carp was carried out. Its juveniles stocks are now ubiquitous in the overgrown zone of the lake. Currently, there are no major threats to the lakes, because of the pritine nature in the broader geographical environs absent of a potential (industrial/agricultural) surface or ground water contamination. On a mid-/long-term, certain risk may represent the shifting terririal climate regime characterized by the rising MAAT, which may negatively affect the aquatic fauna with an undesirable proliferacy of green algae. which may, in turn, have adverse effects to the present biocenoses' balance and ichtyofauna.

The implementation of the ecological monitoring with the water quality and biocenosis control, and the study of changes in the structural and functional organization of aquatic ecosystems under the influence of natural and anthropogenic environmental factors, are the principal conservation priorities of these unique lacustrine basins. The current investigations at the Sibe lakes represent a starting point for a long-term monitoring of the East Kazakhstan freshwater ecosystems. In the broader regional context, the present results on the lakes' geoenvironments and unspoiled aquatic habitats improve our understanding of the terrestrial-aquatic ecosystems' dynamics and the modern human influences upon the pristine parkland-steppe and semi-desert landscapes of Central Asia [107-109]. At the same time, the new knowledge helps to increase the chances for their conservation and sustainable use.

\section{Conclusions}

The hydrobiological studies at the Sibe lakes provided the first complex information on the taxonomic composition and the spatial distribution of zooplankton and macrozoobenthos in the freshwater basins in the arid upland steppes of East Kazakhstan. The analyses confirmed marked variations of the key aquatic ecosystem indicators. The low level of the zooplankton formation in terms of taxonomic richness and overall quantitative indicators corresponds to the (low) level of the lakes' trophicity. The principal zooplankton communities include the characteristic representatives of the aquatic micro-fauna of the physical-geographical zone of the broader Altai region. The zooplankton saprobity index combined with macrozoobenthos and the biotic index indicates clean waters (Lake Tortkara, Sadyrkol, Korzhynkol) to naturally moderately polluted waters (Lake Shalkar). The biotically most diverse and productive macrozoobenthos concentrated in the lakes' littoral 
zones shows favourable biotic and hydro-geological conditions. The macro-organism composition spectrum and the aquatic biomass production in all the lacustrine basins provide the nourishment base to rich ichthyofauna. This, in turn, adds to sportive fishing and enhances the recreational significance of the Sibe lakes opening new options for land-use strategies and a sustainable development in the nearby area.

The performed investigations revealed differences in the specific hydrochemical and hydro-biological parameters and characteristics of the freshwater lakes on a local scale within the Altai foothill parklands-steppes. Under the influence of the strongly continental climate regime and the local geomorphic and geological background, the lakes display a self-regulatory hydro-ecology functioning seen in the aquatic micro-biota. Similar mechanisms are believed to act and apply in other dry-zone areas of central Asia. The presumed freshwater lake ecosystems' fragility imposed by the currently changing climatic and environmental conditions contrast with the relative hydrological and biological stability of the closed and independently functioning lacustrine water bodies in the Kazakhstan steppe regions. The Sibe lakes are an eloquent example of such aquatic ecosystem autonomy.

Author Contributions: Conceptualization, T.N.S., A.B.M. and J.C. (Jiri Chlachula); Data collection T.N.S., A.B.M. and J.C. (Jiri Chlachula); Methodology, A.B.M., J.C. (Jolanta Czerniawska); Formal analysis, T.N.S., A.B.M., J.C. (Jiri Chlachula), L.B.K., S.B.N. and J.C. (Jolanta Czerniawska); Writing—draft, A.B.M. and J.C. (Jiri Chlachula); Writing-Review \& Editing J.C. (Jiri Chlachula) This study results from an independent basic and analytical research of the authors' organizations and institutions (p. 1). All authors have read and agreed to the published version of the manuscript.

Funding: The Astana International University, Nur-Sultan (the 2017-2019 field and laboratory work); the Environmental Research Centre, Stare Mesto (analytical studies).

Institutional Review Board Statement: Not applicable.

Informed Consent Statement: Not applicable.

Data Availability Statement: Data supporting the reported results can be found at the Faculty of Geography and Biology of the Astana International University, Nur-Sultan, Kazakhstan, and the Environmental Research Centre in Stare Mesto, Czech Republic.

Acknowledgments: Field investigations and analytical studies at the Sibe lakes were supported by the Astana International University, the Institute of Geoecology and Geoinformation, Adam Mickiewicz University in Poznan. Analytical processing provided under support of the Altai branch of the Scientific and Production Centre of Fisheries of the Republic of Kazakhstan, LLP.

Conflicts of Interest: The authors declare no conflict of interest.

\section{References}

1. Chambers, P.A.; Lacoul, P.; Murphy, K.J.; Thomaz, S.M. Global diversity of aquatic macrophytes in freshwater. In Freshwater Animal Diversity Assessment. Developments in Hydrobiology; Balian, E.V., Lévêque, C., Segers, H., Martens, K., Eds.; Springer Nature: Cham, Switzerland, 2007; Volume 198, pp. 9-26.

2. Bai, J.; Chen, X.; Li, J.; Yang, L.; Fang, H. Changes in the area of inland lakes in arid regions of central Asia during the past 30 years. Env. Monit Assess 2011, 178, 247-256. [CrossRef] [PubMed]

3. Jones, N.T.; Gilbert, B. Changing climate cues differentially alter zooplankton dormancy dynamics across latitude. J. Anim. Ecol. 2015, 85, 559-569. [CrossRef] [PubMed]

4. Watanabe, T.; Asai, K.; Houki, A. Numerical estimation to organic pollution of flowing water by using the epilithic diatom assemblage diatom assemblage index (DAIpo). Sci. Total Environ. 1986, 55, 209-218. [CrossRef]

5. Berthon, V.; Bouchez, A.; Rimet, F. Using diatom life-forms and ecological guilds toassess organic pollution and trophic level in rivers: A case study of rivers in south-eastern France. Hydrobiologia 2011, 673, 259-271. [CrossRef]

6. Kókai, Z.; Bácsi, I.; Török, P.; Buczkó, K.; Balogh, C.; Tóthmérész, B. Halophilic diatom taxa are sensitive indicators of even short term changes in lowland lotic systems. Acta Bot. Croat 2015, 74, 287-302. [CrossRef]

7. García-Chicote, J.; Armengol, X.; Rojo, C. Zooplankton species as indicators of trophic state in reservoirs from Mediterranean river basins. Inland Waters 2019, 9, 113-123. [CrossRef]

8. Hall, C.M.; Page, S.J. The Geography of Tourism and Recreation: Environment, Place and Space; Routhledge: London, UK; New York, NY, USA, 1999; 309p. 
9. Wall, G. Implications of Global Climate Change for Tourism and Recreation in Wetland Areas. Clim. Chang. 1998, 40, 371-389. [CrossRef]

10. Amirgaliev, N.A. Aral-Syrdarya Basin: Hydrochemistry, Problems of Aquatic Toxicology; Bastau: Almaty, Kazakhstan, 2007; 224p.

11. Zhumagalieva, Z.M. Lake fund of Kazakhstan: Resumé. Doctoral Dissertation, Geographical Sciences, St. Petersburg, Russia, 2006; 27p.

12. Dostaj, Z.D. Management of the Hydroecosystem of Lake Balkash; Institute of Geography: Almaty, Kazakhstan, 2009; 236p.

13. Dmitriev, P.S.; Fomin, I.A.; Bekturganova, M.B. On the issue of the current state and significance of the lakes of the North Kazakhstan region. In Proceedings of the Kozybayev Readings 2013: Kazakhstan in the Cultural and Civilization Processes, Petropavlovsk, Kazakhstan, 15 November 2013; M. Kozybayev NKSU: Petropavlovsk, Kazakhstan, 2013; pp. 158-162.

14. Ismailova, A.A.; Zhamankara, A.K.; Akbaeva, L.K.; Adamov, A.A.; Abakumov, A.I.; Tulegenov, S.A.; Muratov, R.M. Hydrochemical and hydrobiological indicators as characteristics of the ecological state of lakes (by the example of lakes Burabay and Ulken Shabakty). Kazn. Bull. Biol. Ser. 2013, 3, 504-507.

15. Tursunova, A.A. Modern Assessment of Water Resources of the River. Ile Taking into Account the Circulation Processes in the Atmosphere: Author. Doctoral Dissertation, Geographical Sciences, Almaty, Kazakhstan, 2006; 16p.

16. Tursunov, E.A.; Bazhieva, A.M. Small lakes of the Shchuchinsko-Borovsk resort area. Environmental problems and solutions. Hydrometeorol. Ecol. 2013, 2, 172-176.

17. Tursunov, E.A.; Madibekov, A.S.; Kulebaev, K.M. Modern morphometric characteristics of the lakeBalkash. In Scientific Notes of the Russian State Hydrometeorological University; Russian State Hydrometeorological University: Saint-Petersburg, Russia, 2014; Volume 34, pp. 43-47.

18. Barinova, S.S.; Bragina, T.M.; Nevo, E. Algal species diversity of arid region lakes in Kazakhstan and Izrael. Community Ecol. 2009, 10, 7-16. [CrossRef]

19. Caisová, L.; Bašta, T.; Chlachula, J.; Komárek, J.; Husák, S. Taxonomic investigations of the crynobacterial and algal microflora from the Katon-KaragayNational Park (Altai, East Kazakhstan). Biodivers. Res. Conserv. 2010, 15, 45-54.

20. Krupa, E.G. The structure of species dominance in the plankton of the Caspian Sea of Kazakhstan sector. In Several Aspects of Hydro-Ecological Problems of Kazakhstan; Malkovsky, I.M., Ed.; Kaganat: Almaty, Kazakhstan, 2011.

21. Romanova, S.M.; Kazangapova, N.B. Quality of waters lakes Kazakhstan in contemporaneous period (for example of lake Kopa). Int. J. Biol. Chem. 2013, 6, 65-70.

22. Barinova, S.; Krupa, E. Critical environmental factors for photosynthetic organisms of the Shardara Reservoir, Kazakhstan. Bull. Adv. Sci. Res. 2016, 2, 17-27.

23. Klymiuk, V.; Barinova, S. Phytoplankton Cell Size in Saline Lakes. Research Journal of Pharmaceutical. Biol. Chem. Sci. 2016, 7 , 1077-1085.

24. Boros, E.; Jurecska, L.; Tatár, E.; Vörös, L.; Kolpakova, M. Chemical composition and trophic state of shallow saline steppe lakes in central Asia (North Kazakhstan). Environ. Monit Assess 2017, 189, 546. [CrossRef]

25. Gaskova, O.; Kolpakova, M.; Naymushina, O.; Krivonogov, S. Geochemical processes controlling the water chemistry of saline lakes in the northern Kazakhstan region. In Proceedings of the 17th International Multidisciplinary Scientific GeoConference (SGEM 2017), Albena, Bulgaria, 29 June-5 July 2017; pp. 325-334.

26. Jiyenbekov, A.; Barinova, S.; Bigaliev, A.; Nurashov, S.; Sametova, E.; Fahima, T. Algal comparative floristic of the Alakol lake Natural State Reserve and other lakes in Kazakhstan. Moj Ecol. Environ. Sci. 2018, 3, 252-258.

27. Valeev, A.; Karatayev, M.; Abitbayeva, A.; Uxutbayeva, S.; Bektursinova, A.; Sharapkhanova, A. Monitoring Coastline Dynamics of Alakol Lake in Kazakhstan Using Remote Sensing Data. Geosciences 2019, 9, 404-413. [CrossRef]

28. Akhmedenov, K.M. Tourist and recreational potential of the salt lakes of Western Kazakhstan. Geoj. Tour. Geosites 2020, 30, 782-787. [CrossRef]

29. Chlachula, J.; Zhensikbayeva, N.Z.; Yegorina, A.V.; Kabdrakhmanova, N.K.; Czerniawska, J.; Kumarbekuly, S. Territorial Assessment of the East Kazakhstan Geo/Ecotourism: Sustainable Travel Prospects in the Southern Altai Area. Geosciences 2021, 11, 156. [CrossRef]

30. Fránková, M.; Chlachula, J.; Czerniawska, J.; Myrzagaliyeva, A.B.; Doláková, N.; Jankovská, V. Diatom (Bacillariophyceae). Diversity of the Sibinskiye Lakes (East Kazakhstan). 2021, unpublished.

31. Myrzagaliyeva, A.B.; Kozáková, M.; Chlachula, J. Algae diversity of the lakes Sibinskye, East Kazakhstan-International Symposium Microorganisms and the Biosphere Microbios. In Proceedings of the Materials of Symposium, Tashkent, Uzbekistan, 25-27 November 2015; pp. 16-17.

32. Myrzagalieva, A.B.; Chlachula, J.; Czerniawska, J.; Doláková, N.; Jankovská, V. Vascular Flora and Aquatic Ecosystems of Sibinskye Lakes, East Kazakhstan. 2021, unpublished.

33. Filonets, P.P. Essays on the Geography of Internal Waters of Central, Southern and Eastern Kazakhstan (Lakes, Reservoirs and Glaciers); Nauka: Alma-Ata, Kazakhstan, 1981; 292p.

34. Zhensikbayeva, N.Z.; Saparov, K.T.; Chlachula, J.; Yegorina, A.V.; Atasoy, A.; Wendt, J.A. Natural potential of tourism development in southern Altai. Geoj. Tour. Geosites 2018, 21, 200-212.

35. Chlachula, J. Geotourism perspectives in East Kazakhstan. Geogr. Environ. Sustain. 2019, 12, 29-43. [CrossRef] 
36. Chlachula, J. Biodiversity Protection of Southern Altai in the Context of Contemporary Environmental Transformations and Sustainable Development. Sector 2-3 (East Kazakhstan). In Final Report Field Studies; Irbis: Nerudova, Czech Republic, 2007; p. 223.

37. Chlachula, J. Geoheritage of East Kazakhstan. Geoheritage 2020, 12, 91. [CrossRef]

38. Grigoriev, A.A. (Ed.) Kazakhstan. General Physical and Geographical Characteristic; Nauka: Moscow, Russia; Leningrad, Russia, 1950; 492p.

39. Prairie, Y.T.D.; Bird, D.F.; Coll, J.J. The summer metabolic balance in the epilimnion of southeastern Quebec lakes. Limnol. Oceanogr. 2002, 47, 316-321. [CrossRef]

40. Lindström, E.S.; Bergström, A.K. Influence of inlet bacteria on bacterioplankton assemblage composition in lakes of different hydraulic retention time. Limnol. Oceanogr. 2004, 49, 125-136. [CrossRef]

41. Liping, C.; Yin, Z.; Qigen, L.; Zhongjun, H.; Yuejuan, S.; Ziran, P.; Lijing, C. Spatial variations of macrozoobenthos and sediment nutrients in Lake Yangcheng: Emphasis on effect of pen culture of Chinese mitten crab. J. Environ. Sci. 2015, 37, 118-129.

42. Zaharescu, D.G.; Burghelea, C.I.; Hooda, P.S.; Lester, R.N.; Palanca-Soler, A. Small lakes in big landscape: Multi-scale drivers of littoral ecosystem in alpine lakes. Sci. Total Environ. 2016, 551-552, 496-505. [CrossRef]

43. Kivila, E.H.; Luoto, T.; Rantala, M.V.; Kiljuneri, M.; Rauio, M.; Nevalainien, L. Environmental controls on benthic food web functions and carbon resource use in subarctic lakes. Freshw. Biol. 2019, 64, 643-658. [CrossRef]

44. Suturin, A. Biogeochemistry of Lake Baikal Stony Littoral. J. Geosci. Environ. Prot. 2019, 7, 72-79. [CrossRef]

45. Frerencz, B.; Toporowska, M.; Dawidek, J.; Sobolewski, W. Hydro-Chemical Conditions of Shaping the Water Quality of Shallow Łęczna-Włodawa Lakes (Eastern Poland). Clean Soil Air Water 2017. [CrossRef]

46. Encyclopedia Britannica. 2008. Available online: https://www.britannica.com/ (accessed on 1 May 2021).

47. Abakumov, V.A. (Ed.) Guidelines for Methods of Hydrobiological Analysis of Surface Waters and Bottom Sediments; Gidrometeoizdat: Leningrad, Russia, 1983; 240p.

48. Alipoor, V.; Rahimibashar, M.R.; Aliev, A. Temporal and Spatial Variation of Macrozoobenthos in the Chamkhale Estuary (South Caspian Sea). Middle-East J. Sci. Res. 2011, 10, 654-658.

49. Kuzmetov, A.R.; Abdinazarov, X.X. Ecological-faunistic characteristics of reservoirs' zooplankton in Uzbekistan. Eur. J. Chem. Nat. Sci. 2016, 1-2, 3-6. [CrossRef]

50. Abdinazarov, X.; Madumarov, M.; Haydarov, S. Zooplankton of Sarikamish Lake (Uzbekistan). Open Access Libr. J. 2019, 6, 1-8. [CrossRef]

51. Kozhova, O.M.; Izmesteva, L.R.; Erbaeva, E.A. A review of the hydrobiology of Lake Khubsugul (Mongolia). Hydrobiologia 1994, 291, 11-19. [CrossRef]

52. Ermakov, V.V. Geochemical ecology and biogeochemical criteria for estimating the ecologic state of biospheric taxons. Geochem. Int. 2015, 53, 195-212. [CrossRef]

53. Bazarova, B.B.; Tashlykova, N.A.; Afonina, E.Y.; Kuklin, A.P.; Matafonov, P.V.; Tsybekmitova, G.T.; Gorlacheva, E.-P.; Itigilova, M.T.; Afonin, A.V.; Butenko, M.N. Long-term fluctuations of the aquatic ecosystems in the Onon-Torey plain (Russia). Acta Ecol. Sin. 2019, 39, 157-165. [CrossRef]

54. Mannig, B.; Müller, M.; Starke, E.; Merkenschlager, C.; Mao, W.; Zhi, X.; Podzun, R.; Jacob, D.; Paeth, H. Dynamical downscaling of climate change in Central Asia. Glob. Planet. Chang. 2013, 110, 26-39. [CrossRef]

55. Velikovskaya, E.M. Development of the relief of the Southern Altai and Kalba and deep gold-bearing placers. Bull. MOIP Dep. Geol. 1946, 21, 57-77.

56. Velikovskaya, E.M. Pliocene Quaternary deposits and the development of the Kalba relief. Sci. Notes Mosc. State Univ. Geol. 1947, 3, 58-63.

57. Abulkabirova, M.A.; Stroeva, M.N. On the age of granite intrusions in Kalba. Geology 1955, 19, 40-50.

58. Nekhoroshev, V.P. (Ed.) Geology of the USSR. Eastern Kazakhstan. Geology Description; Nedra: Moskow, Russia, 1967; 467p.

59. Veselova, L.K. Morphostructure of the South-Eastern Kazakhstan Mountains. In Geography of Desertic and Mountain Region of Kazakhstan; Nauka: Moskow, Russia; Leningrad, Russia, 1970; pp. 38-48.

60. Aubekerov, B.Z. Stratigraphy and Paleogeography of the Plain Zones of Kazakhstan during the Late Pleistocene and Holocene. Development of Landscape and Climate in Northern Asia in Late Pleistocene and Holocene; Nauka: Moskow, Russia, 1993; pp. 101-110.

61. Galakhov, V.P.; Mukhametov, P.M. Glaciers of the Altai; Nauka: Novosibirsk, Russia, 1999; 136p.

62. Baibatsha, A.B.; Aubekerov, B.J. Quaternary Geology of Kazakhstan; Gylym: Almaty, Kazakhstan, 2003 ; p. 147.

63. Chlachula, J. Pleistocene climate change, natural environments and Palaeolithic occupation of East Kazakhstan. Quat. Int. 2010, 220, 64-87. [CrossRef]

64. Obruchev, V.A. Selected Works on the Geography of Asia; Geografizdat: Moscow, Russia, 1951; Volume 2, 400p.

65. Chupakhin, V. Physical Geographyof Kazakhstan; Mektep Press: Almaty, Kazakhstan, 1968; 260p. (In Russian)

66. Dyachkov, B.A.; Mayorova, N.P.; Chernenko, Z.I. History of East Kazakhstan geological structures development in the Hercynian, Cimmerian and Alpine cycles of tectonic genesis, Part II. In Proceedings of the Ust-Kamenogorsk Kazakh Geographical Society; D. Serikbaev East Kazakhstan State Technical University Press: Ust-Kamenogorsk, Kazakhstan, 2014; pp. 42-48. (In Russian)

67. Chlachula, J. Gemstones of eastern Kazakhstan. Geologos 2020, 26, 125-148. [CrossRef]

68. Weather Atlas. 2021. Available online: https://www.weather-atlas.com/en/kazakhstan/ust-kamenogorsk-climate-rainfall (accessed on 1 May 2021). 
69. Utesheva, A.S. Climate of Kazakhstan; Gidrometeoizdat: Leningrad, Russia, 1959; 368p.

70. Reference Book of Climate in Kazakhstan. Issue 10. East Kazakhstan Region; RSE "Kazhydromet": Almaty, Kazakhstan, 2003; 77p.

71. Yegorina, A.V. Physical Geography of East Kazakhstan; EHI Press: Ust'-Kamenogorsk, Kazakhstan, 2002; 181p. (In Russian)

72. Yegorina, A.V. The Climate of Southwest Altai; Textbook: Semey, Kazakhstan, 2015; 315p.

73. Domanitskiy, A.P. The Rivers and Lakes of the USSR; Gidrometeoizdat: Almaty, Kazakhstan, 1971; 104p. (In Russian)

74. Samarkhanov, T.N.; Yegorina, A.V.; Myrzagalieva, A.B.; Saparov, K.T. Climate factors as an evaluation componentof the recreation potential at the Sibinskiye lakes. Hydrometeorol. Ecol. 2019, 3, 7-21. (In Russian)

75. Lurie, Y.Y. (Ed.) Unified Methods of Analysis of Waters, 2nd ed.; Chemistry: Moscow, Russia, 1973; 376p.

76. Semenov, A.D. (Ed.) Manual to Chemical Analysis of Surface Waters of the Land; Gidrometeoizdat: Leningrad, Russia, 1977; 541p.

77. Reznikov, A.A.; Kulikowska, E.P.; Sokolov, I.Y. Methods of Analysis of Natural Waters, 3rd ed.; Nedra: Moscow, Russia, 1970; 488p.

78. Woodiwiss, F.S. Biotic index of the Trent River. Macroinvertebrates and Biological Studies. In Scientific Principles of Surface Water Quality Control by Hydrobiological Indices. Proceedings USSR-British Work; Gidrometeoizdat: Leningrad, Russia, $1977 ;$ pp. 132-161.

79. Sharapova, L.I.; Falomeeva, A.P. Methodological Manual for Hydrobiological Fishery Studies of Water Bodies of Kazakhstan (Plankton, Zoobentos); Research Institute of Fisheries of the Republic of Kazakhstan: Almaty, Kazakhstan, 2006; 27p.

80. Manuilova, E.F. Cladocera (Cladocera) of the Fauna of the USSR; Nauka: Moscow, Russia; Leningrad, Russia, 1964; 326p.

81. Kutikova, L.A. Rotifers of the Fauna of the USSR (Rotatoria); Nauka: Leningrad, Russia, 1970; 744p.

82. Kutikova, L.A.; Starobogatov, Y.I. (Eds.) Keys to Freshwater Invertebrates of the European Part of the USSR; Gidrometeoizdat: Leningrad, Russia, 1977; 512p.

83. Ibrasheva, S.I.; Smirnova, V.A. Cladocera of Kazakhstan; Mektep: Alma-Ata, Kazakh, 1983; 135p.

84. Balushkina, E.V.; Vinberg, G.G. The relationship between body weight and length in planktonic animals. In General Foundations of the Study of Aquatic Ecosystems; Vinberg, G.G., Ed.; Nauka: Leningrad, Russia, 1979; pp. 169-172.

85. Shitikov, V.K. Quantitative Hydroecology: Methods, Criteria, Solutions; Book 1; Kriskunov, E.A., Ed.; Nauka: Moscow, Russia, 2005; 281p.

86. Chernovsky, A.A. Keys to the Larvae of Mosquitoes of the Family Tendipedidae; USSR, Academy of Sciences: Moscow, Russia; Leningrad, Russia, 1949; 186p.

87. Pankratova, V.Y. Larvae and Pupae of Mosquitoes of the Subfamily Podonominae and Tanypodinae of the USSR Fauna; Nauka: Leningrad, Russia, 1977; 154p.

88. Pankratova, V.Y. Larvae and Pupae of Mosquitoes of the Subfamily Chironominae of the Fauna of the USSR; Nauka: Leningrad, Russia, 1983; 296p.

89. Keskitalo, J.; Salonen, K. Manual for Integrated Monitoring. Subprogramme Hydrobiology of Lakes; Publications of the Water and Environment Administration: Helsinki, Finland, 1994; Volume 16, pp. 26-33.

90. Kitaev, S.P. Ecological Bases of Biological Productivity of Lakes in Different Natural Zones; Nauka: Moscow, Russia, 1984; 207p.

91. Sládeček, V. System of Water Quality from the Biological Point of View. Arch. Hidrobiol. Ergeb. Limnol. 1973, 7, 1-218.

92. Alimov, A.F. Regularities of changes in the structural and functional characteristics of communities of aquatic organisms. Hydrobiol. J. 1995, 31, 3-11.

93. Bakanov, A.I. Using zoobenthos for monitoring freshwater reservoirs (review). Biol. Intern. Waters 2000, 1, 68-82.

94. Macioszczyk, A.; Dobrzyński, D. Hydrogeochemistry. Zone of Active Groundwater Exchange; PWN: Warszawa, Poland, 2007; 448p. (In Polish)

95. Konstantinov, A.S. General Hydrobiology; Nauka: Moskow, Russia, 1986; 472p.

96. Shitikov, V.K.; Zinchenko, T.D.; Golovatyuk, L.V. Assessing Surface Water Quality Based on Indicator Zoobenthos Species. Water Resour. 2004, 31, 323-332. [CrossRef]

97. Perus, J.; Bonsdorff, E.; Baeck, S.; Lax, H.-G.; Villnaes, A.; Westberg, V. Zoobenthos as Indicators of Ecological Status in Coastal Brackish Waters: A Comparative Study from the Baltic Sea. Ambio A J. Hum. Environ. 2007, 36, 250-256. [CrossRef]

98. Pešić, V.; Gadawski, P.; Gligorović, B.; Glöer, P.; Grabowski, M.; Kováče, T.; Murány, D.; Płóciennik, M.; Šundić, D. The Diversity of the zoobenthos communities of the Lake Skadar/Shkodra Basin. In The Skadar/Shkodra Lake Environment, The Handbook of Environmental Chemistry; Pešić, V., Karaman, G., Kostianoy, A., Eds.; Springer: Cham, Switzerland, 2018; Volume 80, pp. 255-294. [CrossRef]

99. Kurmangaliyeva, S.G. Seasonal dynamics of zooplankton in the Lower Kolsay Lakes. Biol. Sci. 1974, 7, 87-91.

100. Krupa, E.G. Zooplankton in Lothic and Limnetic Ecosystems of Kazakhstan. Structure, Patterns Offormation; Palmarium Academic Publishing: Saarbrucken, Germany, 2012; 346p.

101. Smirnova, D.A. State of zooplankton of the Middle and Lower Kolsay Lakes (Chilik river watershed) during the beginning of their recreational use. Kazakh Natl. Univ. Bull. Biol. Ser. 2000, 4, 54-60.

102. Krupa, E.G.; Barinova, S.M.; Romanova, S.M.; Malybekov, A.B. Hydrobiologicalassessment of the high mountain Kolsay Lakes (Kungey Alatau, Southeastern Kazakhstan) ecosystems in climatic gradient. Br. J. Environ. Clim. Chang. 2016, 6, 259-278. [CrossRef]

103. Krupa, E.G.; Barinova, S.S.; Romanova, S.M. Zooplankton size structure in the Kolsay Mountain Lakes (Kungei Alatau, southeastern Kazakhstan) and its relationships with environmental Factors. Water Resour. 2019, 46, 403-414. [CrossRef]

104. Bolduc, P.; Bertolo, A.; Pinel-Alloul, B. Does submerged aquatic vegetation shape zooplankton community structure and functional diversity? A test with a shallow fluvial lake system. Hydrobiologia 2016, 778, 151-165. [CrossRef] 
105. Yapiyev, V.; Samarkhanov, K.; Tulegenova, N.; Jumassultanova, S.; Verhoef, A.; Saidaliyeva, Z.; Umirov, N.; Sagintayev, Z.; Namazbayeva, A. Estimation of water storage changes in small endorheic lakes in Northern Kazakhstan. J. Arid Environ. 2019, 160, 42-55. [CrossRef]

106. Wu, J.; Liu, W.; Zeng, H.; Ma, L.; Bai, R. Water quantity and quality of xix lakes in the arid Xinjiang region, NW China. Environ. Process. 2014, 1, 115-125. [CrossRef]

107. Kamp, J.; Koshkin, M.A.; Hrabina, T.M.; Katzner, T.N.; Milner-Gulland, J.E.; Schreiber, D.; Sheldon, R.; Schmalenko, A.; Smelansky, I.; Terraube, J.; et al. Persistent and novel threats to the biodiversity of Kazakhstan's steppes and semi-deserts. Biodivers. Conserv. 2016, 25, 2521-2541. [CrossRef]

108. Zhaglovskaya, A.; Chlachula, J.; Thevs, N.; Myrzagaliyeva, A.; Aidosova, S. Natural regeneration potential of the black saxaul shrub-forests in semi-deserts of Central Asia-the Ili River delta area, SE Kazakhstan. Pol. J. Ecol. 2017, 3, 352-368. [CrossRef]

109. Bayandinova, S.; Mamutov, Z.; Ispanova, G. Man-Made Ecology of East Kazakhstan; Environmental Science and Engineering; Springer Nature Press: Singapore, 2018; 136p. 